\title{
Mineral chemistry and genetic implications of garnet from the São João del Rei Pegmatitic Province, Minas Gerais, Brazil
}

\author{
Sarah Siqueira da Cruz Guimarães Sousa ${ }^{1,2 *}(\mathbb{D}$, Ciro Alexandre Ávila1,2,3 (®, Reiner Neumann 3,4 (D,

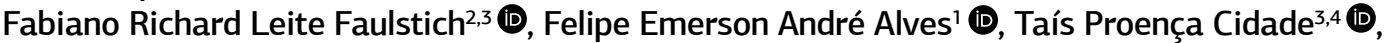 \\ Victor Hugo Riboura Menezes da Silva' (1)
}

\begin{abstract}
The pegmatites of the São João del Rei Pegmatitic Province are related to the Siderian protoliths of the Cassiterita and Resende Costa orthogneisses and to the Ritápolis metagranitoid of Ryacian age. Chemical analysis of garnet from twelve pegmatites reveal two different types of grains, which were found in the same pegmatitic body in six of these samples. One garnet type has almandine-spessartine composition $\left(\mathrm{Sps}_{11.7-58.8} \mathrm{Alm}_{36.8-86.5} \operatorname{Prp}_{0.1-4.1} \mathrm{Grs}_{0.0-1.4} \mathrm{Adr}_{0.0-2.6}\right)$, grains with orange and pink tones, and scarce mineral inclusions. These garnet grains may have been formed at the magmatic stage of pegmatite crystallization. The composition of these grains plot exclusively on the Alm-Sps axis at the $\operatorname{Prp}+\mathrm{Grs}+\mathrm{Adr}+\mathrm{Uvr} \times \mathrm{Alm} \times$ Sps diagram, as expected from garnet crystallized in pegmatites, and an expansion of the field associated to pegmatites is proposed. The second type has a distinct chemical composition $\left(\mathrm{Sps}_{26.9-8.4 .8} \mathrm{Alm}_{3.6-40.0} \operatorname{Prp}_{0.0-10.4} \mathrm{Grs}_{9.3-45.6} \mathrm{Adr}_{0.1-3.4}\right)$, displaying enrichment in $\mathrm{Ca}$. This Ca-enriched garnet has irregular shaped colourless grains and abundant mineral inclusions. These grains may have been formed by Ca-metasomatism during the late-stage crystallization of the pegmatites.
\end{abstract}

KEYWORDS: almandine-spessartine; Ca-enriched garnet; pegmatite; Ca-metasomatism.

\section{INTRODUCTION}

The garnet supergroup includes all isostructural minerals represented by the general chemical formula $\left\{\mathrm{X}_{3}\right\}\left[\mathrm{Y}_{2}\right]\left(\mathrm{Z}_{3}\right) \Phi_{12}$, where $\mathrm{X}, \mathrm{Y}$, and $\mathrm{Z}$ stand for the 12 -fold, 8-fold and 4 -fold coordination sites, respectively, while $\Phi$ is filled with anions such as $\mathrm{O}^{2-}, \mathrm{OH}^{-}$or $\mathrm{F}^{-}$. This supergroup has been subdivided into five groups (henritermierite, bitikleite, schorlomite, berzeliite, and garnet) based on symmetry and total charge at the $Z$ site (Grew et al. 2013). The isometric garnet group, with a total charge at $\mathrm{Z}$ of 12 (occupied by $\mathrm{Si}^{4+}$ ), have the $\mathrm{X}$-site occupied preferably by $\mathrm{Fe}^{2+}, \mathrm{Mn}^{2+}, \mathrm{Mg}^{2+}, \mathrm{Ca}^{2+}$ and the $\mathrm{Y}$ site by $\mathrm{Fe}^{3+}, \mathrm{Al}^{3+}$, and $\mathrm{Cr}^{3+}$ (Fig. 1). According to these occupancies, the endmembers pyrope $\left(\mathrm{Mg}^{2+}, \mathrm{Al}^{3+}\right)$, grossular $\left(\mathrm{Ca}^{2+}, \mathrm{Al}^{3+}\right)$, spessartine $\left(\mathrm{Mn}^{2+}\right.$, $\left.\mathrm{Al}^{3+}\right)$, almandine $\left(\mathrm{Fe}^{2+}, \mathrm{Al}^{3+}\right)$, uvarovite $\left(\mathrm{Ca}^{2+}, \mathrm{Cr}^{3+}\right)$, and andradite $\left(\mathrm{Ca}^{2+}, \mathrm{Fe}^{3+}\right)$ can be formed (Grew et al. 2013).

${ }^{1}$ Programa de Pós-Graduação em Geologia, Universidade Federal do Rio de Janeiro - Rio de Janeiro (RJ), Brazil. E-mails: sarahscgs@gmail.com, avila@ mn.ufrj.br, felipeemersonaalves@gmail.com, vmenezes92@gmail.com

${ }^{2}$ Departamento de Geologia e Paleontologia, Museu Nacional, Universidade Federal do Rio de Janeiro - Rio de Janeiro (RJ), Brazil. E-mail: ffaulstich@mn.ufrj.br

${ }^{3}$ Programa de Pós-Graduação em Geociências, Museu Nacional, Universidade Federal do Rio de Janeiro - Rio de Janeiro (RJ), Brazil. E-mails: rneumann@cetem.gov.br, taiscidade1@gmail.com ${ }^{4}$ Centro de Tecnologia Mineral - Rio de Janeiro (RJ), Brazil. ${ }^{*}$ Corresponding author.
Garnet is a common accessory mineral in igneous and metamorphic rocks (Vennum and Meyer 1979, Baldwin and von Knorring 1983, Harrison 1988, Whitworth and Feely 1994, Gulbin and Glazov 2013), whose composition may vary according to the pressure and temperature conditions that they underwent (Green 1977, Deer et al. 1992). In pegmatites, garnet crystals are predominantly spessartine-rich with subordinate almandine (London 2008). The relation between $\mathrm{Fe}$ and $\mathrm{Mn}$ contents is a useful indicator of fractionation trends in pegmatites and varies in relation to the depth of crystallization and position within individual zoned bodies (Baldwin and von Knorring 1983, Černý et al. 1985, Sokolov and Khlestov 1989). Spessartine-rich garnet is mostly found in evolved pegmatites of the LCT family (Li-Cs-Ta), while almandine-rich component is common in granites and less evolved pegmatites (Baldwin and von Knorring 1983, London 2008). Although being an unusual composition for pegmatites, garnet with enrichment in Ca have been reported worldwide (Novák et al. 2013, Burival and Novák 2018, Tindle et al. 2005, Pieczka et al. 2019), but until now, garnet with this composition has not been described in the São João del Rei Pegmatitic Province.

Except for the pegmatites exploited at the Volta Grande Mine, which are fresh, all pegmatites mapped are deeply weathered, and the resistant accessory minerals are remains of the original mineralogy. The main goal of this work is to report the occurrence of garnet grains of typical chemical composition (Alm-Sps) and garnet grains with enrichment of $\mathrm{Ca}$ in different weathered pegmatitic bodies of the São João del Rei 
Pegmatitic Province. The chemical composition of these garnet types is used here to understand the conditions of formation of these grains and, subsequently, to establish a relation with the petrogenesis of the pegmatites.

\section{GEOLOGICAL CONTEXT OF THE SÃO JOÃO DEL REI PEGMATITIC PROVINCE}

The São João del Rei Pegmatitic Province is a swarm of pegmatitic bodies with variable thicknesses and diverse mineralogy, where part is mineralized in Sn-Nb-Ta (Pereira et al. 2004). This province occupies an area of approximately 2,700 $\mathrm{km}^{2}$, located at the southern border of the São Francisco Craton, within the Mineiro Belt in Southeastern Brazil (Fig. 2).

The Mineiro Belt corresponds to the junction of four magmatic arcs, designated as Cassiterita, Resende Costa, Serrinha, and Ritápolis (Araújo et al. 2019). The Cassiterita, Resende Costa, and Serrinha arcs are mantle-derived, with restricted presence of crustal material and assembled by collisional processes (Ávila et al. 2010, Ávila et al. 2014, Barbosa et al. 2015, Teixeira et al. 2015, Cardoso et al. 2019). These arcs are delimited by extensive structural magnetic lineaments and the final assembly, including the predominantly crustal Ritápolis Arc, was added to the Archean paleocontinent during the interval between the end of the Rhyacian and the beginning of the Orosirian (Araújo et al. 2019).

\section{MINEIRO BELT ARCS AND ITS PEGMATITES}

The Mineiro Belt was subdivided into North and South blocks (Ávila 2000, Ávila et al. 2014), which are separated by a large crustal structure, designated as Lenheiro shear zone (Fig. 2). The North block includes the Cassiterita, Resende Costa, and Ritápolis arcs. It is delimited by the CongonhasItaverava shear zone to the east, the Lenheiro shear zone to the south, and Jeceaba-Bom Sucesso lineament to the north (Ávila et al. 2010, Seixas et al. 2012, Teixeira et al. 2015, Araújo et al. 2019). The South block bears only the Serrinha Arc with its volcanic-subvolcanic components, and is delimited to the north by the Lenheiro shear zone, to the east by the rocks associated with the Mantiqueira Complex, and to the South it is covered by the meso- to neoproterozoic successions (Ávila et al.2014). The pegmatites from the São João del Rei Pegmatitic Province are limited to the North block, occur spatially associated with the Cassiterita, Resende Costa and Ritápolis arcs, and were genetically related to the plutons of these arcs (Tab. 1).

The Cassiterita Arc was formed during the Siderian and is represented by the Cassiterita Orthogneiss and coeval rocks, which present high $\mathrm{Na}_{2} \mathrm{O}$ and low $\mathrm{K}_{2} \mathrm{O}$ contents (Barbosa et al. 2019). The pegmatites associated to the Cassiterita Orthogneiss are 2,489 \pm 10 Ma old (Tab. 1), and mineralized in xenotime, monazite, and microlite while cassiterite, gahnite, and columbite group minerals have not been reported (Faulstich 2016).

The Resende Costa Arc evolved during the Siderian and includes the Restinga de Baixo and Congonhas-Itaverava metavolcano-sedimentary sequences, as well as the Resende Costa and Lagoa Dourada suites. The rocks of these suites vary from tonalitic to granodioritic in composition and exhibit high $\mathrm{Na}_{2} \mathrm{O}$ content (Teixeira et al.2015). The pegmatites associated with the Resende Costa Orthogneiss have been dated by U-Pb LA-ICPMS in zircon between 2,367 \pm 64 and 2,291 $\pm 23 \mathrm{Ma}$ (Tab. 1), and are mineralized in cassiterite, microlite, gahnite, and columbite group minerals (Tab. 2), as well as a diagnostic Nb-Ta-Ti phases intergrowth (Cidade 2019).

The Serrinha Arc, evolved during the Rhyacian, has subvolcanic-volcanic components, and includes the São Sebastião da Vitória metagabbro, Serrinha and Tiradentes suites and the Estação de Tiradentes metasedimentary sequence (Ávila et al. 2014). The Nazareno metavolcano-sedimentary sequence occurs associated to these units, represented by amphibolites, metaultramafic, and metasedimentary rocks (Ávila et al.2012). Intrusive pegmatites are very scarce in these rocks.

The Ritápolis Arc is the youngest one, it evolved during the Rhyacian and is represented by orthogneisses with dioritic to granitic compositions, metadiorites, and metagranitoids.

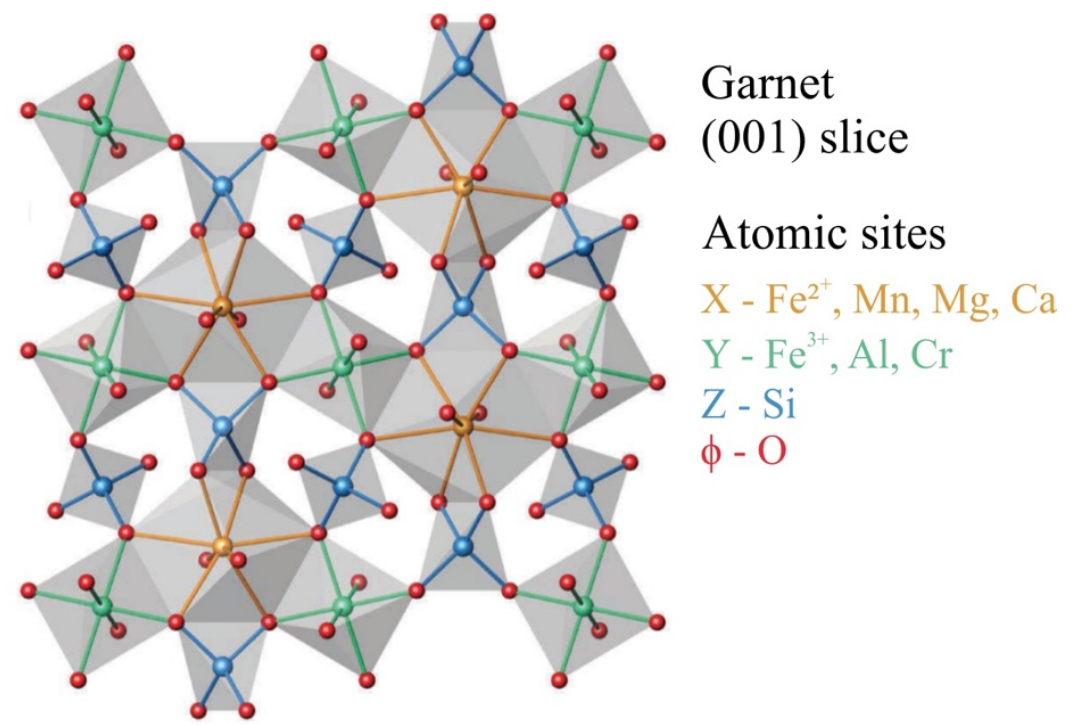

Figure 1. Garnet structure projected along (001) with the element's occupancy for each atomic site (Grew et al. 2013). 
These bodies are calc-alkaline and range from metaluminous to peraluminous (Ávila 2000, Barbosa et al. 2015, Cardoso et al.2019). The pegmatitic bodies are mineralized in cassiterite, columbite group minerals, pyrochlore supergroup minerals, xenotime, gahnite, and monazite (Tab. 2) with U-Pb LA-ICPMS age in zircon between 2,129 \pm 33 and 2,121 $\pm 9 \mathrm{Ma}$ (Faulstich 2016). These pegmatites are similar in age to the Ritápolis metagranitoid, which crystallized between 2,149 \pm 10 (Barbosa et al. 2015) and 2,121 \pm 7 Ma (Ávila 2000).

\section{MATERIALS AND METHODS}

\section{Sampling and preparation}

Approximately $20 \mathrm{~kg}$ of saprolitic material was sampled from each pegmatite intrusive into different host rocks (Fig. 3) and manually preprocessed in local streams. The sampled material was pre-concentrated in the field using a three-step process: washing to remove silt and clay fraction associated to feldspar weathering; sieving at $2 \mathrm{~mm}$ to separate the coarse fraction; and panning to remove quartz, altered feldspar, and
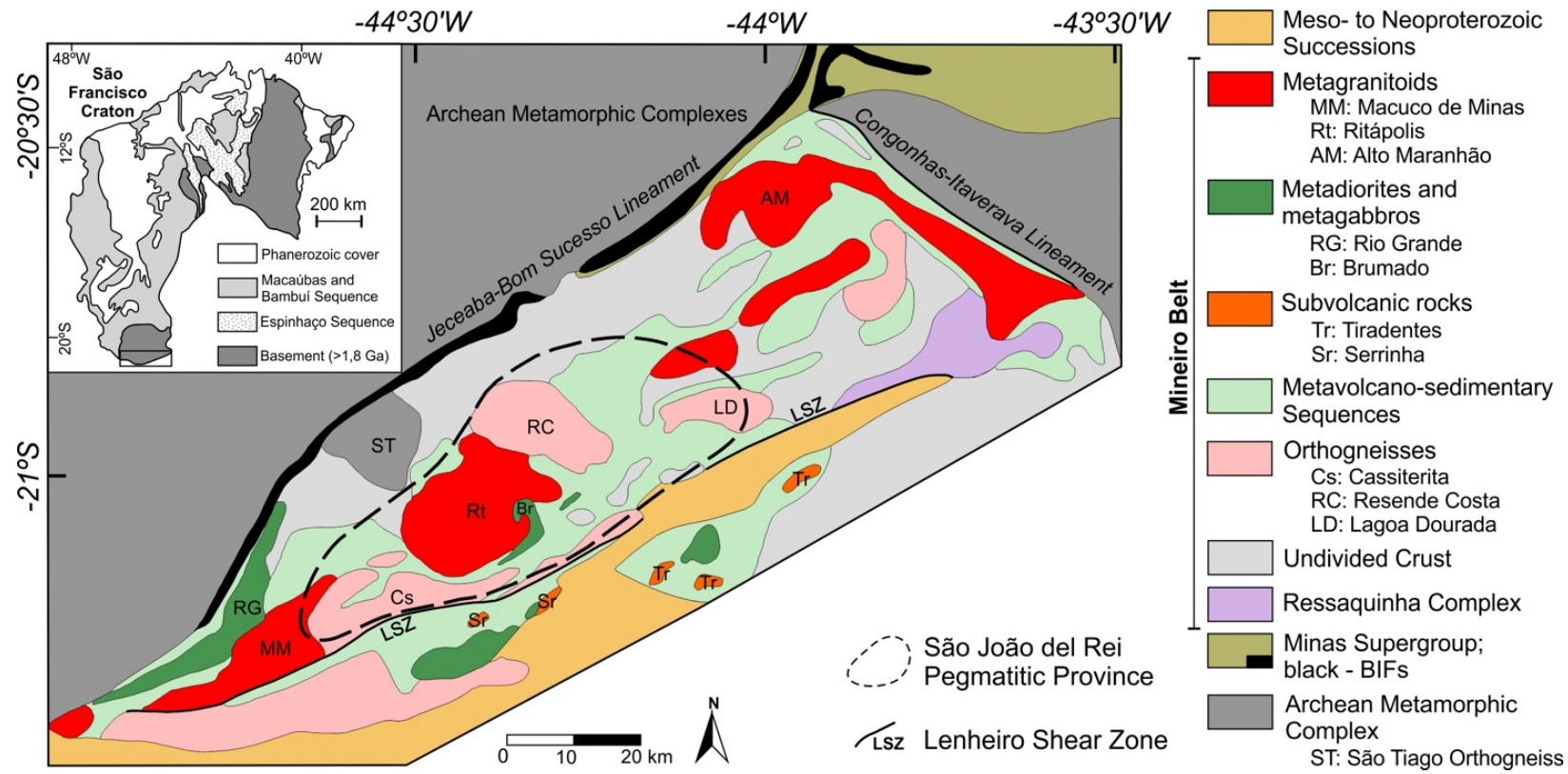

Figure 2. Simplified geological map of the Mineiro Belt (modified from Barbosa et al. 2015, Cardoso et al. 2019) with the delimitation of the São João del Rei Pegmatitic Province. The location of the area in the southern edge of the São Francisco Craton is depicted in the insert (from Alkmim and Martins Neto 2012).

Table 1. Crystallization age of the Mineiro Belt main rocks and its intrusive pegmatites.

\begin{tabular}{|c|c|c|c|c|}
\hline \multirow{2}{*}{$\begin{array}{l}\text { Mineiro } \\
\text { Belt blocks }\end{array}$} & \multirow{2}{*}{$\begin{array}{l}\text { Mineiro } \\
\text { Belt arcs }\end{array}$} & \multirow{2}{*}{$\begin{array}{l}\text { Main } \\
\text { Rocks }\end{array}$} & \multicolumn{2}{|c|}{ U/Pb Cristallyzation Age } \\
\hline & & & Host rocks & $\begin{array}{c}\text { Intrusive } \\
\text { pegmatites }\end{array}$ \\
\hline \multirow{8}{*}{ North } & \multirow{4}{*}{$\begin{array}{l}\text { Ritápolis } \\
\text { Arc }\end{array}$} & Metadiorites and associated metatonalites & $2,145 \pm 7-2,102 \pm 33 \mathrm{Ma}^{1,2}$ & \multirow{4}{*}{$\begin{array}{c}2,129 \pm 33-2,121 \\
\pm 9 \mathrm{Ma}^{9}\end{array}$} \\
\hline & & Metagranitoids & $2,149 \pm 10-2,121 \pm 7 \mathrm{Ma}^{1,3}$ & \\
\hline & & Dioritic to granitic orthogneisses & $2,191 \pm 9-2,146 \pm 5 \mathrm{Ma}^{4-7}$ & \\
\hline & & $\begin{array}{c}\text { Rio das Mortes } \\
\text { metavolcano-sedimentary sequence }\end{array}$ & $2,231 \pm 5-2,202 \pm 11 \mathrm{Ma}^{8}$ & \\
\hline & \multirow{3}{*}{$\begin{array}{l}\text { Resende } \\
\text { Costa Arc }\end{array}$} & $\begin{array}{c}\text { Restinga de Baixo } \\
\text { metavolcano-sedimentary sequence }\end{array}$ & $2,317 \pm 16 \mathrm{Ma}^{10}$ & \multirow{3}{*}{$\begin{array}{c}2,367 \pm 64- \\
2,291 \pm 23 \mathrm{Ma}^{12}\end{array}$} \\
\hline & & $\begin{array}{l}\text { Congonhas-Itaverava metavolcano- } \\
\text { sedimentary sequence }\end{array}$ & $\begin{array}{l}\text { maximum deposition age: } \\
2,349 \pm 14 \mathrm{Ma}^{10}\end{array}$ & \\
\hline & & Resende Costa and Lagoa Dourada Suites & $2,356 \pm 3-2,351 \pm 48 \mathrm{Ma}^{10,11}$ & \\
\hline & $\begin{array}{l}\text { Cassiterita } \\
\text { Arc }\end{array}$ & Cassiterita Orthogneiss and coeval rocks & $2,472 \pm 11-2,414 \pm 29 \mathrm{Ma}^{13}$ & $2,489 \pm 10 \mathrm{Ma}^{9}$ \\
\hline \multirow{4}{*}{ South } & \multirow{4}{*}{$\begin{array}{l}\text { Serrinha } \\
\text { Arc }\end{array}$} & $\begin{array}{l}\text { Estação de Tiradentes } \\
\text { metasedimentary sequence }\end{array}$ & $\begin{array}{l}\text { maximum deposition age: } \\
2,088 \pm 12 \mathrm{Ma}^{4}\end{array}$ & \multirow{4}{*}{$\begin{array}{l}\text { No pegmatite } \\
\text { described }\end{array}$} \\
\hline & & São Sebastião da Vitória metagabbro & $2,220 \pm 3 \mathrm{Ma}^{14}$ & \\
\hline & & Serrinha and Tiradentes suites & $2,227 \pm 22-2,204 \pm 11 \mathrm{Ma}^{4,15}$ & \\
\hline & & Nazareno metavolcano-sedimentary sequence & $2,267 \pm 14-2,223 \pm 4 \mathrm{Ma}^{8}$ & \\
\hline
\end{tabular}

${ }^{1}$ Barbosa et al. (2015); ${ }^{2}$ Cardoso et al. (2019); ${ }^{3}$ Ávila (2000); ${ }^{4}$ Ávila et al. (2014); ${ }^{5}$ Ávila et al. (2006); ${ }^{6}$ Teixeira et al. (2008); ${ }^{7}$ Vasconcelos et al. (2017); ${ }^{8}$ Ávila et al. (2012); ${ }^{9}$ Faulstich (2016); ${ }^{10}$ Teixeira et al. (2015); ${ }^{11}$ Seixas et al. (2012); ${ }^{12}$ Cidade (2019); ${ }^{13}$ Barbosa et al. (2019); ${ }^{14}$ Valença et al. (2000); ${ }^{15}$ Ávila et al. (2010). 
Braz. J. Geol. (2021), 51(1): e20190136

Table 2. Main heavy minerals assembly from pegmatites of the São João del Rei Pegmatitic Province, selected for this study.

\begin{tabular}{|c|c|c|c|c|c|c|c|c|c|c|c|c|}
\hline Samples & $\begin{array}{c}\text { FA } \\
08\end{array}$ & $\begin{array}{l}\text { SR } \\
04\end{array}$ & $\begin{array}{l}\text { SR } \\
15\end{array}$ & $\begin{array}{l}\text { SR } \\
17\end{array}$ & $\begin{array}{l}\text { SR } \\
23\end{array}$ & $\begin{array}{c}\text { CA } \\
01\end{array}$ & $\begin{array}{l}\text { LE } \\
01\end{array}$ & $\begin{array}{c}\text { LE } \\
10\end{array}$ & $\begin{array}{c}\text { LE } \\
08\end{array}$ & $\begin{array}{l}\text { TA } \\
04\end{array}$ & $\begin{array}{l}\text { TA } \\
05\end{array}$ & $\begin{array}{l}\text { TA } \\
09\end{array}$ \\
\hline \multirow{2}{*}{ Host rock } & \multicolumn{6}{|c|}{ Rio das Mortes MVSS } & \multirow{2}{*}{\multicolumn{6}{|c|}{ RCO }} \\
\hline & \multicolumn{2}{|c|}{$\mathbf{R M}$} & $\mathbf{P}$ & $\mathbf{A}$ & G & $A(V G)$ & & & & & & \\
\hline Garnet group minerals & $\mathrm{x}$ & $\mathrm{x}$ & $\mathrm{x}$ & $\mathrm{x}$ & $\mathrm{x}$ & $\mathrm{x}$ & $\mathrm{x}$ & $\mathrm{x}$ & $\mathrm{x}$ & $\mathrm{x}$ & $\mathrm{x}$ & $\mathrm{x}$ \\
\hline Ilmenite & $\mathrm{x}$ & $\mathrm{x}$ & $\mathrm{x}$ & $\mathrm{x}$ & & $\mathrm{x}$ & $\mathrm{x}$ & $\mathrm{x}$ & & $\mathrm{x}$ & & $\mathrm{x}$ \\
\hline Monazite & $\mathrm{x}$ & $\mathrm{x}$ & $\mathrm{x}$ & $\mathrm{x}$ & & $\mathrm{x}$ & $\mathrm{x}$ & $\mathrm{x}$ & $\mathrm{x}$ & $\mathrm{x}$ & & $\mathrm{x}$ \\
\hline Xenotime & $\mathrm{x}$ & $\mathrm{x}$ & $\mathrm{x}$ & $\mathrm{x}$ & & & & $\mathrm{x}$ & $\mathrm{x}$ & $\mathrm{x}$ & & $\mathrm{x}$ \\
\hline Columbite group minerals & $\mathrm{x}$ & & $\mathrm{x}$ & $\mathrm{x}$ & $\mathrm{x}$ & $\mathrm{x}$ & & $\mathrm{x}$ & $\mathrm{x}$ & & $\mathrm{x}$ & \\
\hline Pyrochlore supergroup minerals & $\mathrm{x}$ & & & & $\mathrm{x}$ & $\mathrm{x}$ & & $\mathrm{x}$ & & & $\mathrm{x}$ & \\
\hline Biotite & $\mathrm{x}$ & $\mathrm{x}$ & $\mathrm{x}$ & & $\mathrm{x}$ & $\mathrm{x}$ & & $\mathrm{x}$ & & & & \\
\hline Muscovite & $\mathrm{x}$ & & $\mathrm{x}$ & $\mathrm{x}$ & $\mathrm{x}$ & & & $\mathrm{x}$ & & & & \\
\hline Tourmaline & $\mathrm{x}$ & $\mathrm{x}$ & $\mathrm{x}$ & $\mathrm{x}$ & $\mathrm{x}$ & & & & & & & \\
\hline Zircon & & $\mathrm{x}$ & $\mathrm{x}$ & $\mathrm{x}$ & $\mathrm{x}$ & $\mathrm{x}$ & $\mathrm{x}$ & $\mathrm{x}$ & $\mathrm{x}$ & $\mathrm{x}$ & $\mathrm{x}$ & $\mathrm{x}$ \\
\hline Gahnite & $\mathrm{x}$ & & $\mathrm{x}$ & $\mathrm{x}$ & & $\mathrm{x}$ & & $\mathrm{x}$ & & $\mathrm{x}$ & $\mathrm{x}$ & \\
\hline Cassiterite & $\mathrm{x}$ & & & $\mathrm{x}$ & & $\mathrm{x}$ & $\mathrm{x}$ & $\mathrm{x}$ & $\mathrm{x}$ & $\mathrm{x}$ & $\mathrm{x}$ & $\mathrm{x}$ \\
\hline $\mathrm{Nb}-\mathrm{Ta}-\mathrm{Ti}$ intergrowth & & & & & & & $\mathrm{x}$ & $\mathrm{x}$ & $\mathrm{x}$ & $\mathrm{x}$ & $\mathrm{x}$ & $\mathrm{x}$ \\
\hline Apatite & $\mathrm{x}$ & & & & & $\mathrm{x}$ & & & & & & \\
\hline Holmquistite & & & & & & $\mathrm{x}$ & & & & & & \\
\hline Spodumene & & & & & & $\mathrm{x}$ & & & & & & \\
\hline Lepidolite & & & & & & $\mathrm{x}$ & & & & & & \\
\hline
\end{tabular}

RM: Ritápolis metagranitoid; MVSS: metavolcano-sedimentary sequence; P: phyllite; A: amphibolite; G: gondite; VG: Volta Grande mine; RCO: Resende Costa Orthogneiss.

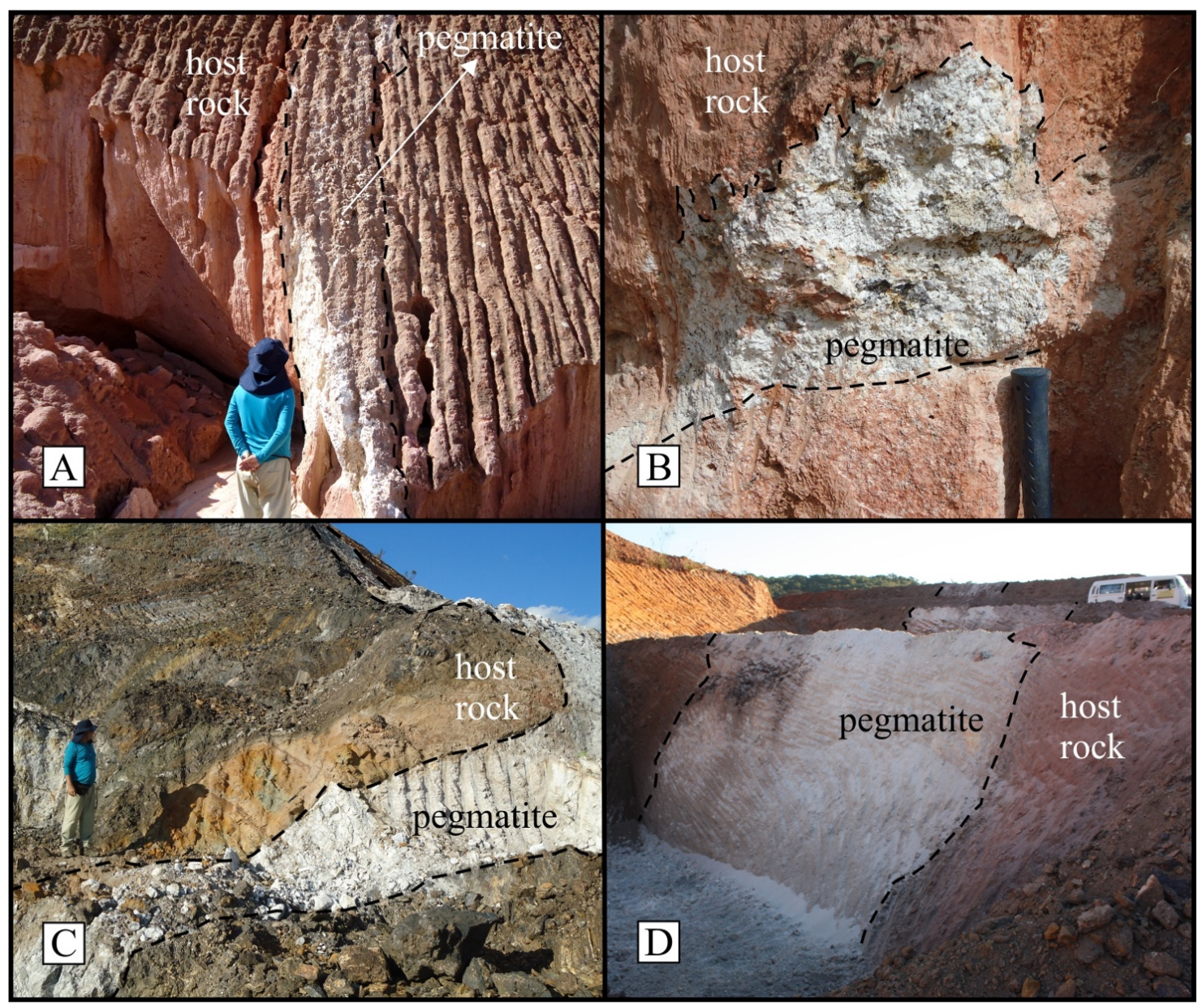

Figure 3. Examples of pegmatites cross-cutting different weathered host rocks of the São João del Rei Pegmatitic Province. All rocks are deeply weathered and only the pegmatite saprolites were sampled for this study. (A) Pegmatite dike intrusive in the Ritápolis metagranitoid. (B) Pegmatite cross-cutting the Resende Costa Orthogneiss. (C and D) Pegmatites intrusive in amphibolites, phyllites, and gondites of the Rio das Mortes metavolcano-sedimentary sequence. 
mica group minerals. The use of this kind of material (pegmatite's saprolite) is useful because we can access most of the accessory minerals without the need to crush or to use another destructive method. Washing the kaolinized feldspar is enough to liberate the grains with their original form preserved. Sample CA-01 is an exception for this kind of preparation. It corresponds to the fresh pegmatitic body A of the Volta Grand mine, and the samples were collected from the mineral processing plant, provided by AMG Mineração S.A. (see more in Alves et al. 2019). Samples FA-08 and SR-04 correspond to pegmatites cross-cutting the Ritápolis metagranitoid. Samples LE-01, LE-08, LE-10, TA-04, TA-05, and TA-09 are pegmatites intrusive into the Resende Costa Orthogneiss. The other samples correspond to pegmatites intrusive in phyllites (sample: SR-15), amphibolites (samples: SR- 17 and CA-01), and gondites (sample: SR-23) of the Rio das Mortes metavolcano-sedimentary sequence.

At the laboratory, the pre-concentrated of heavy minerals were ultrasonically cleansed of adhering clays and $\mathrm{Fe}$ and $\mathrm{Al}$ oxides/hydroxides coating. After being oven-dried, the material was immersed in a high-density liquid - bromoform $(\mathrm{D}=$ $2.89 \mathrm{~g} / \mathrm{cm}^{3}$ ) to remove the light minerals. Magnetic separation was performed with a ferrite magnet and Frantz isodynamic magnetic separator. The products of interest (0.3 and $0.5 \mathrm{~A})$ were analyzed under the stereomicroscope and, for each sample, at least ten garnet grains were hand-picked to cover the widest possible variety of crystals using characteristics such as color, form, and size. These grains were mounted in epoxy resin, ground and polished with diamond discs and suspensions to achieve a mirror finish, and then carbon coated.

\section{Analytical techniques}

Garnet grains of 12 pegmatitic bodies from the São João del Rei Pegmatitic Province (Fig. 4) were analyzed. Optical descriptions were achieved using an Olympus SZX7 stereomicroscope. Backscattered electron (BSE) images were acquired with a FEI Quanta 400 scanning electron microscope (SEM) coupled to a Bruker Quantax 800 energy dispersive spectrometer (EDS) with Bruker XFlash 6|60 detector. Secondary electron images were acquired using a Hitachi TM3030 scanning electron microscope. All these analyses were carried out at the Center for Mineral Technology (CETEM).

The garnet chemical composition was further characterized at the Regional Center for Technological Development and Innovation of the Universidade Federal de Goiás, using a Jeol JXA-8230 Electron Microprobe (EMPA) with five wavelength-dispersion spectrometers. The crystals used for each element analysis were: TAP for $\mathrm{Si}, \mathrm{Al}$ and $\mathrm{Mg}$; PET/L for Ca; $\mathrm{PET} / \mathrm{L}-\mathrm{H}$ for $\mathrm{Ti}$; and $\mathrm{LiF}-\mathrm{L} / \mathrm{H}$ for $\mathrm{Mn}$ and Fe. The analyses were performed under a beam condition of $15 \mathrm{kV}$ and $20 \mathrm{nA}$ with $1 \mu \mathrm{m}$ beam diameter, and analysis time ranging from 20 to 60 seconds per element according to the expected abundance in the mineral. The $\mathrm{x}$-ray intensities were processed by ZAF correction procedure in each analyzed point. The following

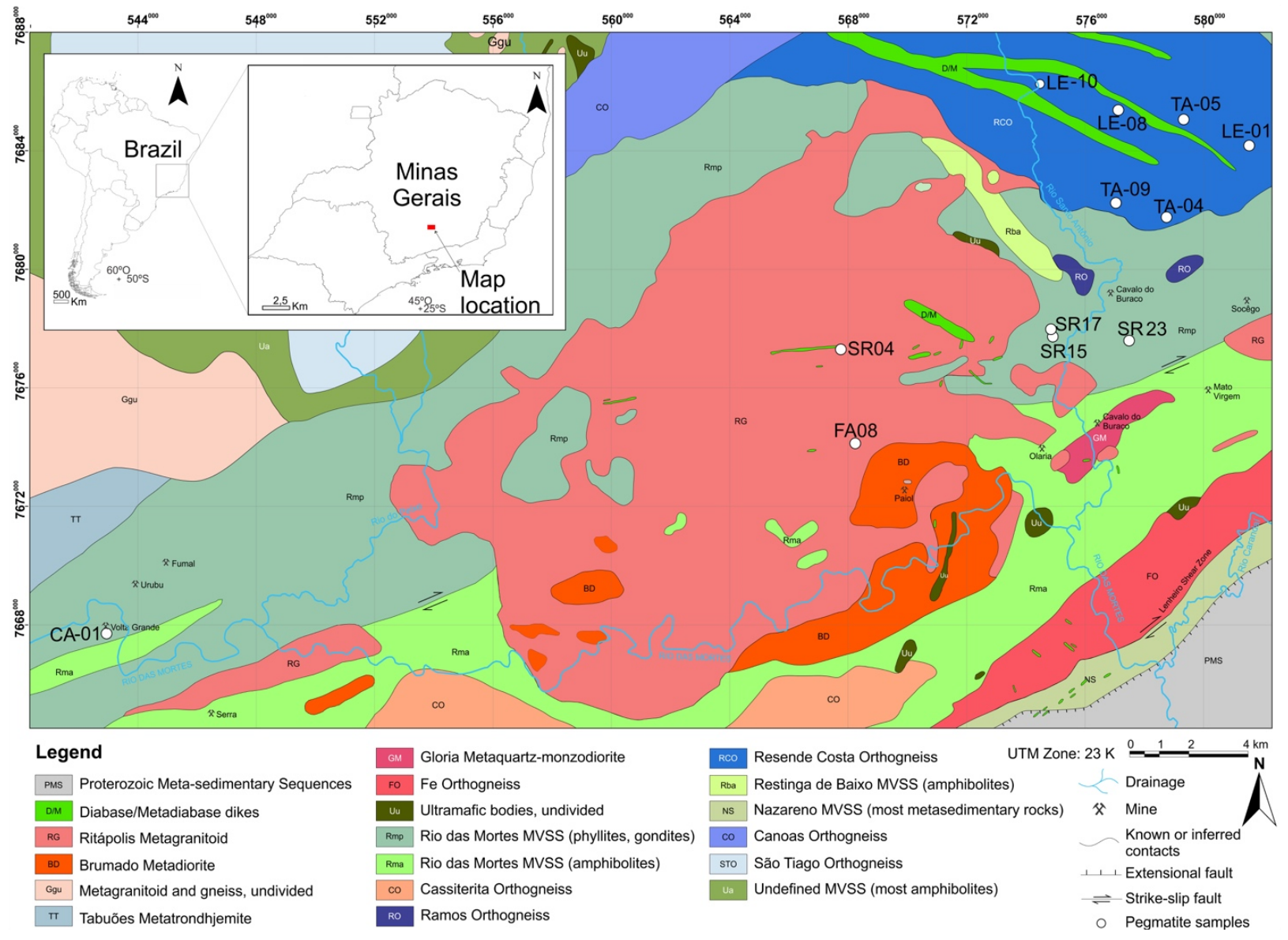

MVSS: metavolcano-sedimentary sequences.

Source: modified from Ávila (2000), Toledo (2002), Souza (2009), Faulstich et al. (2016) and Ávila et al. (2019).

Figure 4. Lithological map of the São João del Rei Pegmatitic Province with the location of sampled pegmatites. 
standards (acquired by Prof. Ian Steele, University of Chicago) and X-rays were used: olivine $(\mathrm{Mg} \mathrm{K} \alpha), \mathrm{Al}_{2} \mathrm{O}_{3}(\mathrm{Al} \mathrm{K \alpha})$, enstatite ( $\mathrm{Si} \mathrm{K} \alpha)$, A480 (Ca K $\alpha$ ), ilmenite ( $\mathrm{Ti} \mathrm{K} \alpha), \mathrm{MnO}_{2}(\mathrm{Mn}$ $\mathrm{K} \alpha$ ), and $\mathrm{Fe}_{3} \mathrm{O}_{4}(\mathrm{Fe} \mathrm{K} \alpha)$. The $\mathrm{Fe}^{2+}$ and $\mathrm{Fe}^{3+}$ content was re-calculated following the procedure described by Droop (1987) and the end-members spessartine, almandine, pyrope, grossular, and andradite were calculated according to the procedure described by Locock (2008).

\section{RESULTS}

\section{Physical properties}

The garnet grains are transparent, homogeneous and vary from euhedral (trapezoidal and dodecahedral forms) to anhe$\mathrm{dral}$. The size of most crystals does not exceed $500 \mu \mathrm{m}$, however some grains can have sizes up to $2 \mathrm{~mm}$ in diameter. The crystals are pink, orange or colourless and display vitreous luster (Figs. 5A, 5B, 5C, 5E, 5F and G). Some grains present rough and dark surface probably due to the oxidation of Fe and $\mathrm{Mn}$ (Figs. 5D and 5H).

\section{Chemical composition}

A total of 81 EMPA analysis revealed a variable chemical composition of the garnet grains, specially its $\mathrm{Fe}, \mathrm{Mn}$, and $\mathrm{Ca}$ contents (Tab. 3). Due to the heterogeneous composition, color, and morphology of the grains, the garnet was subdivided into two distinct types:

- Alm-Sps type, which corresponds to the regular shaped pink and orange grains (Figs. 6A, 6B, and 6C);

- Ca-enriched garnet type, related to the irregular shaped colourless grains (Figs. 6D, 6E, and 6F).

The Alm-Sps grains have $\mathrm{FeO}+\mathrm{MnO}$ content that ranges from 40.75 to 43.91 wt. \%, while the Ca-enriched garnet grains have the sum of $\mathrm{FeO}$ and $\mathrm{MnO}$ ranging from 23.83 to 38.24 wt. \%. The Alm-Sps grains have low content of $\mathrm{CaO}$ (between 0.19 and 1.15 wt. \%), while the Ca-enriched garnet displays high $\mathrm{CaO}$ content, ranging from 4.05 to $16.70 \mathrm{wt}$. \%. Both AlmSps and Ca-enriched garnet types were found in the same pegmatitic body for samples FA-08, SR-15, SR-17, SR-23, CA-01, and TA-05. For samples SR-04, LE-01, LE-08, TA-04, and TA-09, only the Alm-Sps type were reported, while for sample LE-10, only the Ca-enriched garnet was observed (Tab. 3).

Based on the molar proportion of the endmembers, the garnet was characterized by compositional ranges. The AlmSps garnet type composition was defined by the range $\mathrm{Sps}_{11.7}$. ${ }_{58.8} \mathrm{Alm}_{36.8-86.5} \operatorname{Prp}_{0.1-4.1} \mathrm{Grs}_{0.0-1.4} \mathrm{Adr}_{0.0-2.6}$. The exception is related to three grains of sample TA-04A2 (Tab. 3), rich in Sps molecules with an average composition of $\mathrm{Sps}_{92,9} \mathrm{Alm}_{6.0} \mathrm{Grs}_{0.1} \mathrm{Adr}_{1.0}$. The Ca-enriched garnet type shows enrichment in Grs and lower content of Alm molecules and has a composition defined by the ranges $\mathrm{Sps}_{26.9-84.8} \mathrm{Alm}_{3.6-40.0} \operatorname{Prp}_{0.0-10.4} \mathrm{Grs}_{9.3-45.6} \mathrm{Ad}_{0.1-3.4^{\circ}}$.

Concentrations of $\mathrm{TiO}_{2}$ are lower on the Alm-Sps than the Ca-enriched garnet, ranging from 0.00 to 0.14 wt. \% (mean 0.03 wt. \%) and from 0.00 to 0.41 wt. \% (mean 0.10 wt. \%), respectively.

\section{Morphology, texture and inclusions}

Generally, Alm-Sps grains are well formed, with regular faces (Figs. 6A, 6B and 6C) and stepped surfaces (Figs. 7A, $7 \mathrm{~B}$ and $7 \mathrm{C}$ ), while the $\mathrm{Ca}$-enriched garnet grains exhibit sinuous faces with striking indentations (Fig. 6D) and irregular rough surfaces (Figs. 7D, 7E and 7F). The Alm-Sps grains reveal homogeneous gray level in BSE images for almost all samples, characterizing the absence of significant chemical zoning (Figs. 6A, 6B and 6C). Heterogeneous Ca-enriched garnet grains display complex chemical zonation due to the variation of Ca content (Fig. 6F).

Mineral inclusions in garnet grains are absent (Figs. 6A and 6B) or scarce. Quartz and xenotime (Fig. 6C) are the predominant inclusions while zircon, pyrite (Fig. 6D), feldspar,

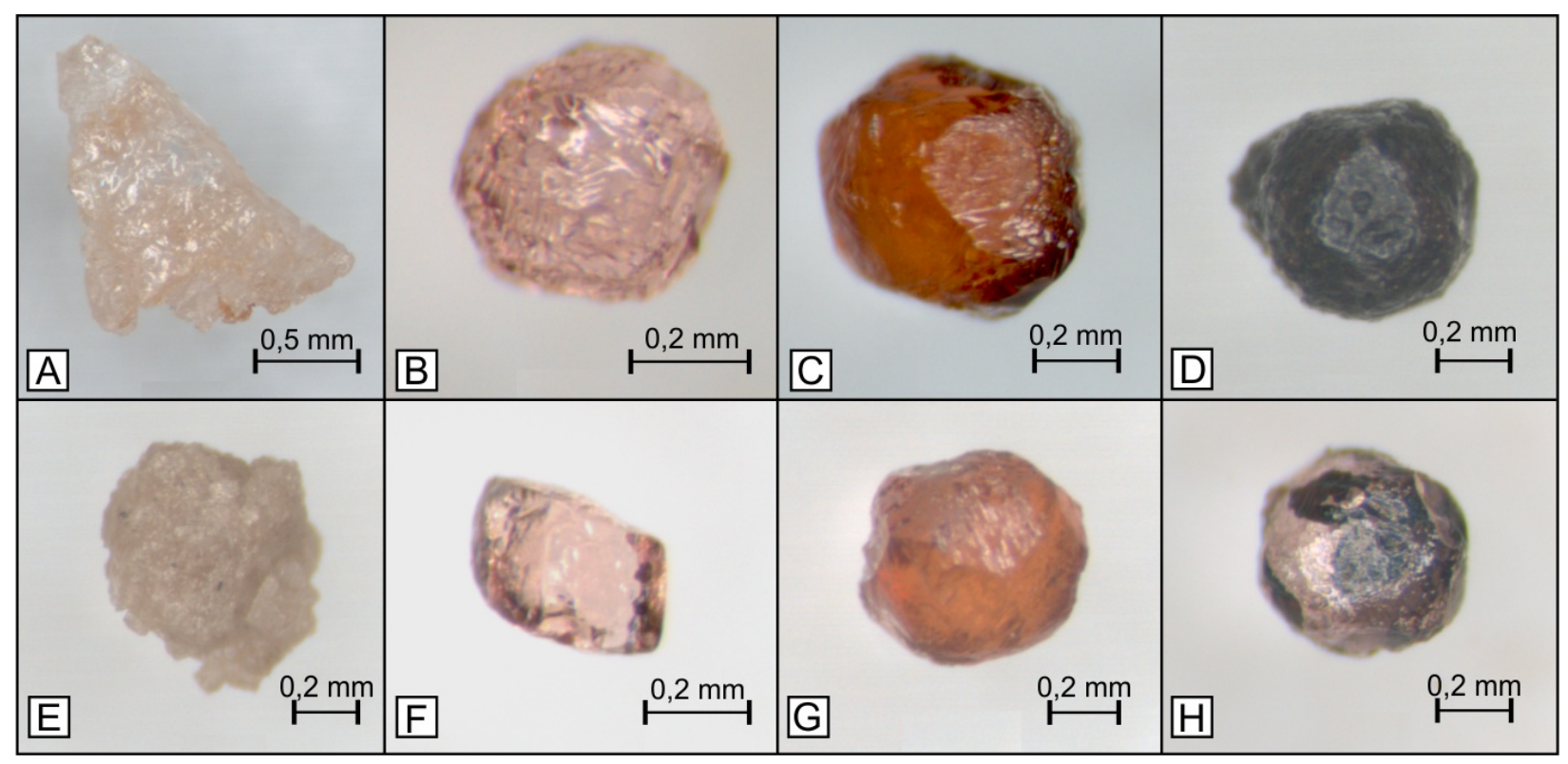

Figure 5. Different colours and shapes of garnet grains under the stereomicroscope. (A and E) Fragments of colourless crystals. (B and F) Pink grains, the former dodecahedral with rounded appearance and the latter one a fragment. (C and $G$ ) Dodecahedral orange grains. (D and $\mathrm{H})$ Grains with dark surface due to the oxidation of $\mathrm{Fe}$ and $\mathrm{Mn}$ by weathering. 
Table 3. Chemical composition (by electron microprobe analysis), atomic proportion and endmembers of Alm-Sps and Ca-enriched garnet grains of the São João del Rei Pegmatitic Province. $\mathrm{FeO}$ and $\mathrm{Fe}_{2} \mathrm{O}_{3}$ recalculated according to Droop (1987). Sample name includes garnet type A for the Alm-Sps grains and B for the Ca-enriched garnet grains.

\begin{tabular}{|c|c|c|c|c|c|c|c|c|c|c|c|c|c|c|c|c|c|c|c|}
\hline \multirow{2}{*}{$\begin{array}{l}\text { Garnet } \\
\text { grains }\end{array}$} & \multicolumn{12}{|c|}{ Almandine-spessartine type } & \multicolumn{7}{|c|}{ Ca-enriched garnet type } \\
\hline & $\begin{array}{c}\text { SR } \\
\text { 04A }\end{array}$ & $\begin{array}{c}\text { FA } \\
\mathbf{0 8 A}\end{array}$ & $\begin{array}{c}\text { SR } \\
15 A\end{array}$ & $\begin{array}{c}\text { SR } \\
\text { 17A }\end{array}$ & $\begin{array}{c}\text { SR } \\
\text { 23A }\end{array}$ & $\begin{array}{c}\text { CA } \\
01 A\end{array}$ & $\begin{array}{c}\text { LE } \\
01 A\end{array}$ & $\begin{array}{c}\text { LE } \\
\mathbf{0 8 A}\end{array}$ & $\begin{array}{c}\text { TA } \\
\text { 04A1 }\end{array}$ & $\begin{array}{c}\text { TA } \\
\text { 04A2 }\end{array}$ & $\begin{array}{c}\text { TA } \\
05 A\end{array}$ & $\begin{array}{c}\text { TA } \\
\text { 09A }\end{array}$ & $\begin{array}{c}\text { FA } \\
\text { O8B }\end{array}$ & $\begin{array}{c}\text { SR } \\
15 B\end{array}$ & $\begin{array}{c}\text { SR } \\
\text { 17B }\end{array}$ & $\begin{array}{c}\text { SR } \\
\text { 23B }\end{array}$ & $\begin{array}{c}\text { CA } \\
01 B\end{array}$ & $\begin{array}{c}\text { LE } \\
\text { 10B }\end{array}$ & $\begin{array}{c}\text { TA } \\
\text { 05B }\end{array}$ \\
\hline Host rocks & $\mathbf{R M}$ & $\mathbf{R M}$ & $\mathbf{P}$ & $\mathbf{A}$ & $\mathbf{G}$ & $\begin{array}{c}\mathbf{A} \\
(\mathbf{V G})\end{array}$ & RCO & RCO & RCO & RCO & RCO & RCO & $\mathbf{R M}$ & $\mathbf{P}$ & $\mathbf{A}$ & $\mathbf{G}$ & $\begin{array}{c}\mathbf{A} \\
(\mathbf{V G})\end{array}$ & RCO & RCO \\
\hline$n=81$ & 4 & 14 & 4 & 4 & 4 & 2 & 5 & 5 & 3 & 3 & 2 & 5 & 2 & 4 & 4 & 4 & 4 & 5 & 3 \\
\hline \multicolumn{20}{|c|}{ Oxides (wt. \%) } \\
\hline $\mathrm{SiO}_{2}$ & 35.97 & 36.26 & 36.07 & 36.04 & 35.88 & 36.35 & 36.12 & 36.01 & 35.55 & 35.97 & 36.45 & 36.11 & 37.90 & 36.81 & 36.92 & 36.68 & 37.64 & 37.45 & 36.75 \\
\hline $\mathrm{TiO}_{2}$ & 0.02 & 0.02 & 0.02 & 0.01 & 0.02 & 0.01 & 0.11 & 0.02 & 0.08 & 0.00 & 0.00 & 0.01 & 0.09 & 0.32 & 0.14 & 0.02 & 0.11 & 0.04 & 0.04 \\
\hline $\mathrm{Al}_{2} \mathrm{O}_{3}$ & 20.39 & 19.42 & 20.47 & 20.83 & 20.38 & 19.75 & 19.86 & 20.45 & 20.31 & 20.55 & 20.16 & 20.19 & 20.15 & 20.53 & 20.88 & 20.88 & 20.37 & 20.23 & 20.37 \\
\hline $\mathrm{FeO}$ & 34.80 & 31.65 & 32.33 & 36.22 & 24.98 & 28.38 & 19.76 & 20.57 & 2.59 & 19.45 & 19.06 & 21.11 & 9.44 & 5.45 & 5.78 & 3.48 & 17.21 & 8.87 & 2.34 \\
\hline $\mathrm{Fe}_{2} \mathrm{O}_{3}$ & 0.00 & 0.00 & 0.00 & 0.00 & 0.00 & 0.00 & 0.00 & 0.00 & 0.22 & 0.00 & 0.00 & 0.00 & 0.00 & 0.00 & 0.00 & 0.00 & 0.00 & 0.00 & 0.75 \\
\hline $\mathrm{MnO}$ & 7.53 & 10.84 & 10.06 & 6.70 & 17.90 & 15.32 & 22.08 & 20.44 & 39.64 & 22.53 & 22.23 & 21.26 & 20.17 & 29.25 & 30.28 & 31.91 & 15.80 & 20.63 & 32.72 \\
\hline $\mathrm{MgO}$ & 0.44 & 0.90 & 0.52 & 0.30 & 0.07 & 0.08 & 0.86 & 0.99 & 0.00 & 0.58 & 0.84 & 0.67 & 1.55 & 0.30 & 0.34 & 0.37 & 1.36 & 0.27 & 0.61 \\
\hline $\mathrm{CaO}$ & 0.77 & 0.45 & 0.33 & 0.19 & 0.43 & 0.21 & 0.86 & 0.44 & 0.63 & 0.87 & 1.15 & 0.66 & 8.82 & 7.27 & 5.48 & 6.30 & 6.88 & 12.12 & 6.52 \\
\hline Total & 99.92 & 99.54 & 99.80 & 100.29 & 99.66 & 100.10 & 99.65 & 98.92 & 99.02 & 99.95 & 99.89 & 100.01 & 98.12 & 99.93 & 99.82 & 99.64 & 99.41 & 99.61 & 100.09 \\
\hline \multicolumn{20}{|c|}{ Atomic proportions (basis 12 oxygen) } \\
\hline $\mathrm{Si}$ & 2.98 & 3.01 & 2.99 & 2.98 & 2.98 & 3.01 & 2.98 & 2.99 & 2.96 & 2.96 & 3.00 & 2.98 & 3.07 & 2.98 & 3.00 & 2.98 & 3.05 & 3.01 & 2.97 \\
\hline $\mathrm{Ti}$ & 0.00 & 0.00 & 0.00 & 0.00 & 0.00 & 0.00 & 0.01 & 0.00 & 0.01 & 0.00 & 0.00 & 0.00 & 0.01 & 0.02 & 0.01 & 0.00 & 0.01 & 0.00 & 0.00 \\
\hline $\mathrm{Al}$ & 1.99 & 1.90 & 2.00 & 2.03 & 2.00 & 1.93 & 1.93 & 2.00 & 1.99 & 2.00 & 1.95 & 1.96 & 1.92 & 1.96 & 2.00 & 2.00 & 1.94 & 1.92 & 1.94 \\
\hline $\mathrm{Fe}^{2+}$ & 2.38 & 2.17 & 2.21 & 2.47 & 1.71 & 1.90 & 1.35 & 1.41 & 0.18 & 1.32 & 1.29 & 1.44 & 0.64 & 0.36 & 0.39 & 0.23 & 1.15 & 0.59 & 0.16 \\
\hline $\mathrm{Fe}^{3+}$ & 0.00 & 0.00 & 0.00 & 0.00 & 0.00 & 0.07 & 0.00 & 0.00 & 0.01 & 0.00 & 0.00 & 0.00 & 0.00 & 0.00 & 0.00 & 0.00 & 0.00 & 0.00 & 0.04 \\
\hline $\mathrm{Mn}$ & 0.53 & 0.76 & 0.71 & 0.47 & 1.26 & 1.08 & 1.55 & 1.44 & 2.80 & 1.57 & 1.55 & 1.48 & 1.38 & 2.01 & 2.08 & 2.20 & 1.08 & 1.41 & 2.24 \\
\hline $\mathrm{Mg}$ & 0.05 & 0.11 & 0.06 & 0.04 & 0.01 & 0.01 & 0.11 & 0.12 & 0.00 & 0.07 & 0.10 & 0.08 & 0.19 & 0.04 & 0.04 & 0.04 & 0.16 & 0.03 & 0.07 \\
\hline $\mathrm{Ca}$ & 0.07 & 0.04 & 0.03 & 0.02 & 0.04 & 0.02 & 0.08 & 0.04 & 0.06 & 0.08 & 0.10 & 0.06 & 0.76 & 0.63 & 0.48 & 0.55 & 0.60 & 1.05 & 0.57 \\
\hline \multicolumn{20}{|c|}{ Endmembers (mol\% normalized) } \\
\hline Spessartine & 17.74 & 26.41 & 23.64 & 15.75 & 42.26 & 36.93 & 52.67 & 48.08 & 94.86 & 53.04 & 51.66 & 50.26 & 47.96 & 67.50 & 69.65 & 73.72 & 37.18 & 47.29 & 76.24 \\
\hline Pyrope & 1.82 & 3.86 & 2.14 & 1.22 & 0.28 & 0.00 & 3.63 & 4.11 & 0.00 & 2.38 & 3.42 & 2.81 & 6.49 & 1.22 & 1.36 & 1.49 & 4.89 & 0.01 & 2.48 \\
\hline Almandine & 78.19 & 68.41 & 73.31 & 82.48 & 56.25 & 62.45 & 41.44 & 46.57 & 4.45 & 41.98 & 41.53 & 44.97 & 22.16 & 11.03 & 13.12 & 6.46 & 39.99 & 17.82 & 4.10 \\
\hline Grossular & 0.82 & 0.00 & 0.15 & 0.55 & 0.33 & 0.00 & 0.00 & 0.77 & 0.00 & 1.39 & 0.76 & 0.00 & 23.39 & 18.17 & 15.87 & 17.86 & 17.94 & 31.65 & 14.86 \\
\hline Andradite & 1.44 & 1.32 & 0.77 & 0.00 & 0.87 & 0.62 & 2.25 & 0.46 & 0.69 & 1.20 & 2.63 & 1.96 & 0.00 & 2.08 & 0.00 & 0.47 & 0.00 & 3.23 & 2.32 \\
\hline
\end{tabular}

n: number of analysis; RM: Ritápolis metagranitoid; P: phyllite; A: amphibolite; G: gondite from the Rio das Mortes metavolcano-sedimentary sequence; VG: Volta Grande mine; RCO: Resende Costa Orthogneiss.

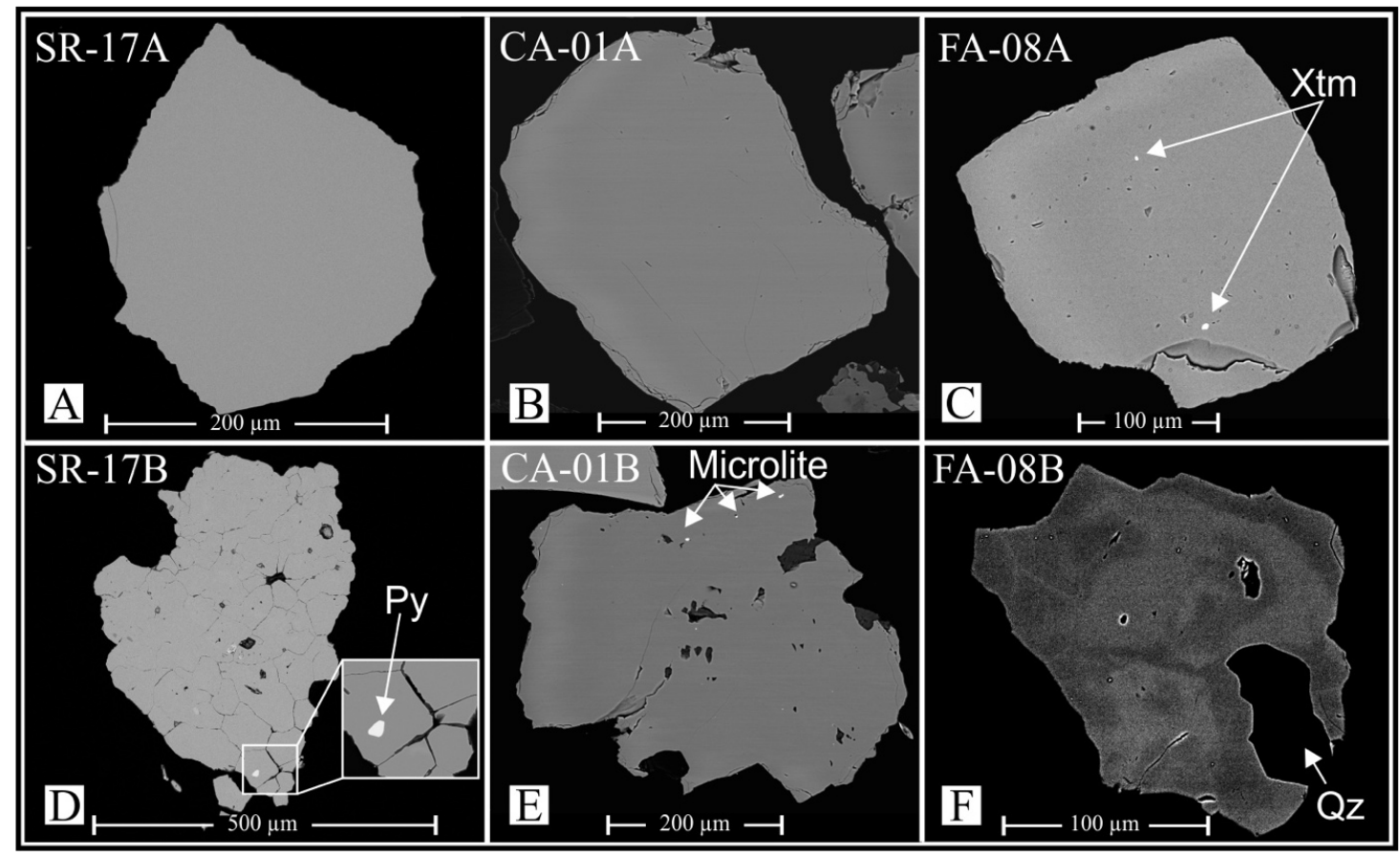

Figure 6. Backscattered electron images of (A, B and C) Alm-Sps grains and (D, E and F) Ca-enriched garnet grains. (A and B) Grains without solid inclusions and chemical zoning; (C) scarce inclusions of xenotime (Xtm); (D) grain with sinuous contour and pyrite (Py) inclusion; (E) grain with sinuous contour and microlite inclusions; F: chemical zoning due variable amounts of Ca. 
biotite, muscovite, ilmenite, cassiterite, rutile, microlite group minerals, columbite subgroup minerals, and $\mathrm{Nb}$-Ta-Ti phases are rare. Cassiterite and $\mathrm{Nb}-\mathrm{Ta}$-Ti phases intergrowth inclusions occur only in garnet grains from pegmatites intrusive into the Resende Costa Orthogneiss; inclusions of columbite subgroup minerals are found in garnet from pegmatites intrusive into the Ritápolis metagranitoid; and inclusions of rutile and microlite (Fig. $6 \mathrm{E}$ ) are present only in garnet from the pegmatite of the Volta Grande mine.

\section{DISCUSSION}

\section{Garnet composition on provenance diagrams}

Garnet geochemistry is widely used as a tool for investigation of sediment provenance for many reasons, such as: common presence in heavy mineral assemblages of different rocks; stability under weathering and diagenesis; and a wide range in major element composition (Morton 1985, Morton et al. 2004, Mange and Morton 2007). Due to the variable chemical composition, several diagrams were established to characterize the rock-source of the main garnet endmembers found in sedimentary sequences (Sabeen et al. 2002, Mange and Morton 2007).

The provenance diagrams proposed by Mange and Morton (2007) and Remus et al. (2004), based on the main cations of the garnet, have delimited compositional fields that imply in different lithological sources (Fig. 8). On the Prp $\times$ Alm + Sps $\times$ Grs+Adr+Uvr diagram (Mange and Morton 2007), the A field corresponds to a Mg-rich and Ca-poor garnet from high-grade metasedimentary rocks or charnockites. The B field comprises the $\mathrm{Mn}$-rich and $\mathrm{Mg}$-poor garnet, subdivided into the Bi field for garnet with $\mathrm{XCa}<10 \%$, derived from intermediate-acid igneous rocks and the Bii field, for garnet with $\mathrm{XCa}>10 \%$, which occurs on the low- to medium-grade metasedimentary rocks. The $\mathrm{C}$ field includes $\mathrm{Mg}$-rich and $\mathrm{Ca}$-rich garnet and was subdivided into $\mathrm{Ci}(\mathrm{XMg}<40 \%)$ and $\mathrm{Cii}(\mathrm{XMg}>40 \%)$ fields for garnet from metamafic and metaultramafic rocks, respectively. The D field correspond to Fe-rich and Ca-rich garnet that is common in metasomatic rocks such as skarns. The Prp+Grs+Adr+Uvr $\times$ Alm $\times$ Sps diagram (Remus et al. 2004) proposed an E field for Mn-rich, Fe-rich, Mg-poor, and Ca-poor garnet typical of pegmatites and aplitic granites.

The chemical composition of the garnet types of the São João del Rei Pegmatite Province were plotted on the Mange and Morton (2007) diagram. All Alm-Sps grains fit in the Bi field (Fig. 8A), as expected for acid igneous rocks. The Ca-enriched garnet grains, however, are distributed heterogeneously in the Bii field, which is related to low- to medium-grade metasedimentary rocks (Fig. 8A). On the diagram of Remus et al. (2004), Alm-Sps grains plots on the E field, that implies pegmatitic source, but several of these grains exhibit a higher almandine/ spessartine ratio than that proposed by the authors, suggesting an extension of this field of up to $90 \%$ of almandine content (Fig. 8B). The Ca-enriched garnet grains plot entirely outside the proposed area for pegmatites (Fig. 8B).

\section{Fractionation of the pegmatitic bodies}

Granite-pegmatite systems show an enrichment of $\mathrm{Mn}$ in the melt as a result of fractionation (Maner et al. 2019). According to Černý et al. (1985), the Fe/Mn ratio decreases, and the Mn content increases in garnet crystals with progressive fractional crystallization of granites and pegmatites. Plotting the garnet composition of this study on the $\mathrm{Fe} / \mathrm{Mn} \times \mathrm{Mn}$ (wt. $\%$ ) diagram, the Ca-enriched garnet data does not fit along the curve observed for granites and pegmatites worldwide (Fig. 9). Assuming that the $\mathrm{Fe} / \mathrm{Mn}$ ratio would not be affected by the Ca substitution, the data were back-calculated removing the $\mathrm{Ca}$ content and re-normalizing the $\mathrm{Mn}$ and Fe contents (Fig. 9A). Considering the fractionation trend of the Alm-Sps grains, the

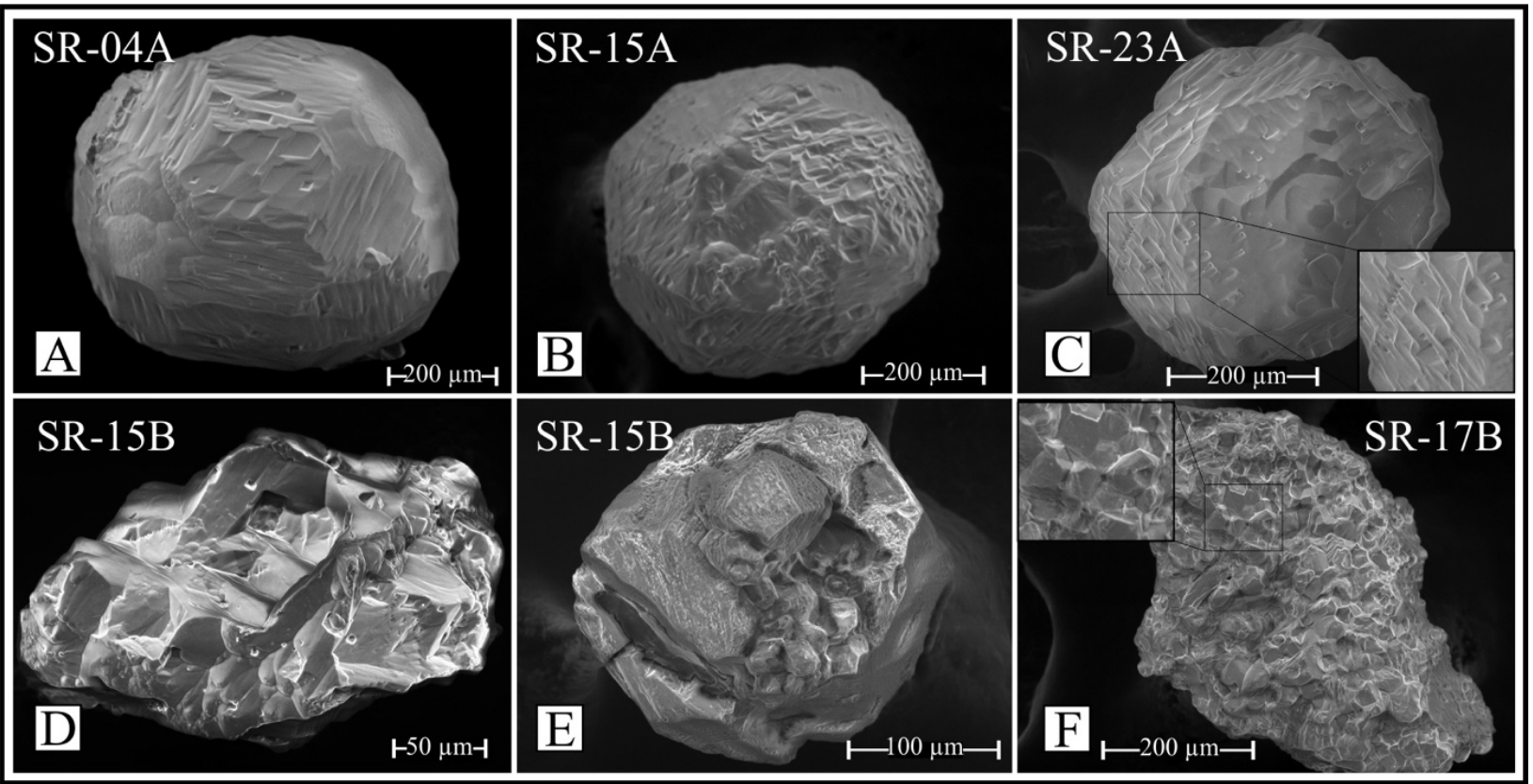

Figure 7. Secondary electrons images of (A, B and C) Alm-Sps grains and (D, E and F) Ca-enriched garnet grains. Inserts in C (detail of a grain with stepped surface), and $\mathrm{F}$ (detail of irregular rough surface). 
most evolved pegmatites among this group would be the ones hosted by the Resende Costa Orthogneiss, followed by the pegmatites hosted by the Rio das Mortes metavolcano-sedimentary sequence and then, the pegmatites intrusive in the Ritápolis metagranitoid.
The Ca-enriched garnet grains have a higher content of $\mathrm{Mn}$ and lower Fe/Mn ratio, when compared to the Alm-Sps grains, and consequently plot in the end of the fractionating curve (Fig. 9A). Considering each pegmatite that hosts two garnet types (Fig. 10), the trend of crystallization shows an

Host
rocks

Rio das Mortes MVSS

Resende Costa orthogneiss

Ritápolis metagranitoid

\begin{tabular}{|c|}
\hline $\begin{array}{l}\text { Garnet } \\
\text { composition }\end{array}$ \\
\hline $\begin{array}{l}\triangle \text { Alm-Sps } \\
\triangle \text { Ca-enriched }\end{array}$ \\
\hline $\begin{array}{l}\text { Alm-Sps } \\
\diamond \text { Ca-enriched }\end{array}$ \\
\hline $\begin{array}{l}\text { Alm-Sps } \\
\text { Ca-enriched }\end{array}$ \\
\hline
\end{tabular}
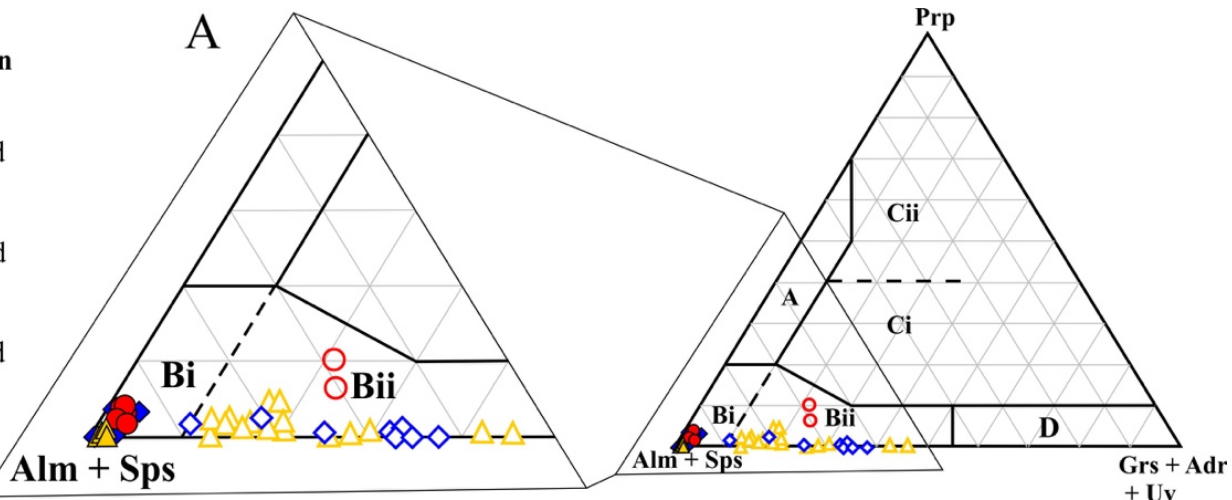

B
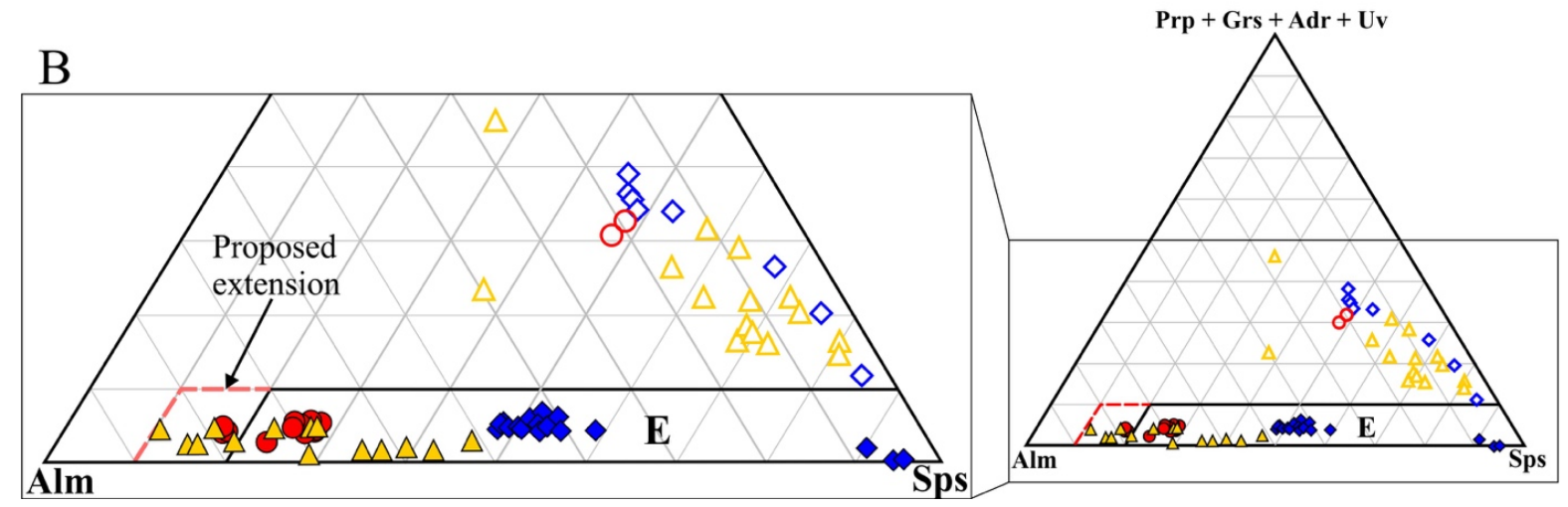

Prp: pyrope; Grs: grossular; Adr: andradite; Uv: uvarovite; Alm: almandine; Sps: spessartine; MVSS: metavolcano-sedimentary sequence.

Figure 8. Ternary diagrams of provenance applied to the chemical composition of garnet grains of the São João del Rei Pegmatitic Province. (A) Fields proposed by Mange and Morton (2007): (A) Charnockites or metasedimentary rocks of granulite facies; (Bi) Granitoids and pegmatites; (Bii) Low to medium grade metasedimentary rocks; (Ci) Amphibolites and basic orthogneisses; (Cii) Metaultramafic rocks; (D) Calcissilicatic and metacarbonatic rocks. (B) Field proposed by Remus et al. (2004): (E) Pegmatites and granitic aplites. The red dashed corresponds to the proposed $\mathrm{E}$ field expansion in this work. Informations about pegmatite samples and their host rocks are in Table 3.

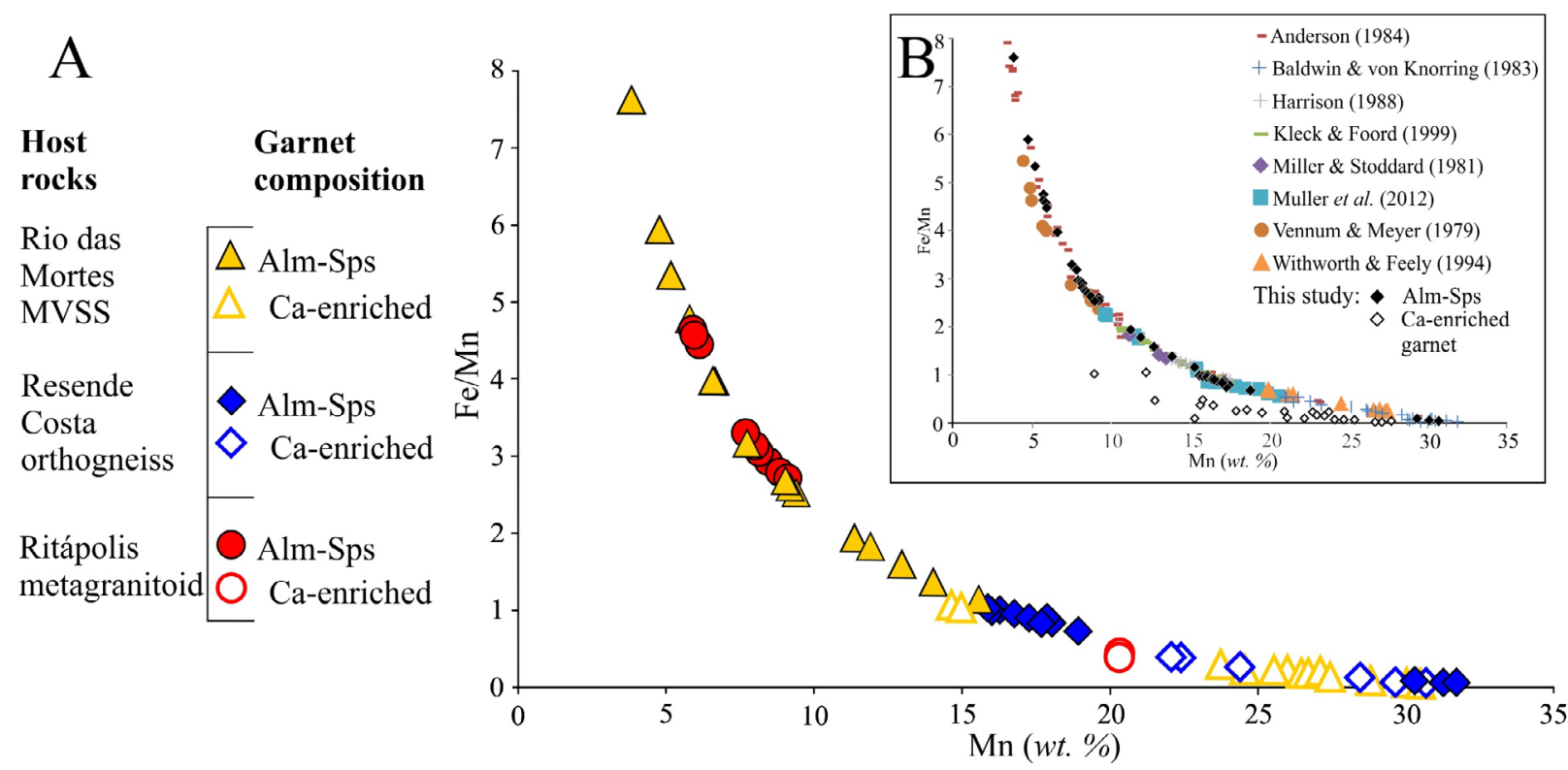

Figure 9. $\mathrm{Fe} / \mathrm{Mn} \times \mathrm{Mn}$ (wt. \%) diagram proposed by Černý et al. (1985) applied to the chemical composition of garnet grains from the pegmatites of the São João del Rei Pegmatitic Province. The pegmatite's host rocks are in the graphic's caption. (A) Evolutionary trend of the Alm-Sps and the Ca-enriched garnet grains with Fe and Mn contents back-calculated removing the Ca excess; (B) Comparison of the Alm-Sps and Ca-enriched garnet grains (without removing the Ca excess) with published garnet data from pegmatites (Baldwin and von Knorring 1983, Anderson 1984, Whitworth and Feely 1994, Kleck and Foord 1999, Müller et al. 2012) and other felsic plutonic rocks (Harrison 1988, Miller and Stoddard 1981, Vennum and Meyer 1979). 
evolution from the Alm-Sps type to the Ca-enriched garnet type, evidencing that these garnet grains originate from a highly evolved fluid or melt.

\section{Ca-metasomatism evidences}

One of the evidences that a pegmatite has undergone Ca-metasomatism is the occurrence of Ca-bearing minerals formed by replacement or modified by fluid overprints (Martin and De Vito 2014, Pieczka et al.2019). The mineralogy of the samples revealed that Ca-bearing minerals (Tab. 2), such as apatite $\left[\mathrm{Ca}_{5}\left(\mathrm{PO}_{4}\right)_{3}(\mathrm{OH}, \mathrm{F}, \mathrm{Cl})\right]$, which was observed at samples FA-08 and CA-01 (Volta Grande mine) are present only in pegmatites that contain $\mathrm{Ca}$-enriched garnet. Alves et al. (2019) reported $\mathrm{Ca}$ and $\mathrm{Li}$ rich hydrothermal fluids, responsible for re-equilibrating apatite in the dissolution-reprecipitation process and forming rare earth elements (REE) phosphates inclusions (monazite and xenotime) at the Volta Grande mine pegmatite. According to the authors, the dissolution-reprecipitation process may have occurred at the late stage of the pegmatite crystallization. The presence of Ca-enriched garnet in the Volta Grande mine (CA-01 sample) is consistent with this hypotesis, and the Ca-enriched garnet is another product of this metasomatic alteration.

An example of garnet overprinted by fluid, which represents an evidence of Ca-metasomatism, is a remarkable garnet grain with $\mathrm{Alm}$-Sps composition showing $\mathrm{Ca}$-rich portions (Figs. 11A, 11B and 11C). This enrichment is accompanied by other elements, such as $\mathrm{Ti}$ (Fig. 11F), which is higher in the Ca-enriched garnet than in Alm-Sps and could be explained by increased Ti solubility with higher Ca contents (Ackerson et al.2017). As the composition of these Ca-enriched portions present in Alm-Sps grains match the composition of grains composed exclusively of Ca-enriched garnet (Fig. 11F and Tab. 3), it might reveal a partial replacement of the Alm-Sps grain by Ca-metasomatism. If this process is fully carried out (dissolving and reprecipitating the crystal), this may explain the presence of $\mathrm{Ca}$-enriched garnet in these pegmatites.

\section{Origin of Ca supply}

The late enrichment of $\mathrm{Ca}$ in pegmatites is not fully understood and the knowledge about the origin of $\mathrm{Ca}$ is controversial (Burival and Novák 2018). The hypothesis includes:

- melt contamination by host rocks before and after the emplacement (Novák et al. 1999, Tindle et al.2005, Martin and De Vito 2014);

- internal sources, such as albitization of calcic plagioclase, inducing Ca-enrichment of the melt or fluid in the late stage of crystallization (Pieczka et al. 2019).

Ca-enriched garnet is widespread at the pegmatites of São João del Rei Pegmatitic Province. This garnet composition was observed in pegmatites hosted by diverse lithotypes, such as amphibolites, phyllites, gondites, orthogneisses, and metagranitoids. Hence, the contamination during or after the emplacement of several pegmatites intrusive into remarkably different host rocks seems to be less probable.

The available geochronological data (Tab. 1) indicate that the studied pegmatites are part of, at least, two genetically distinct

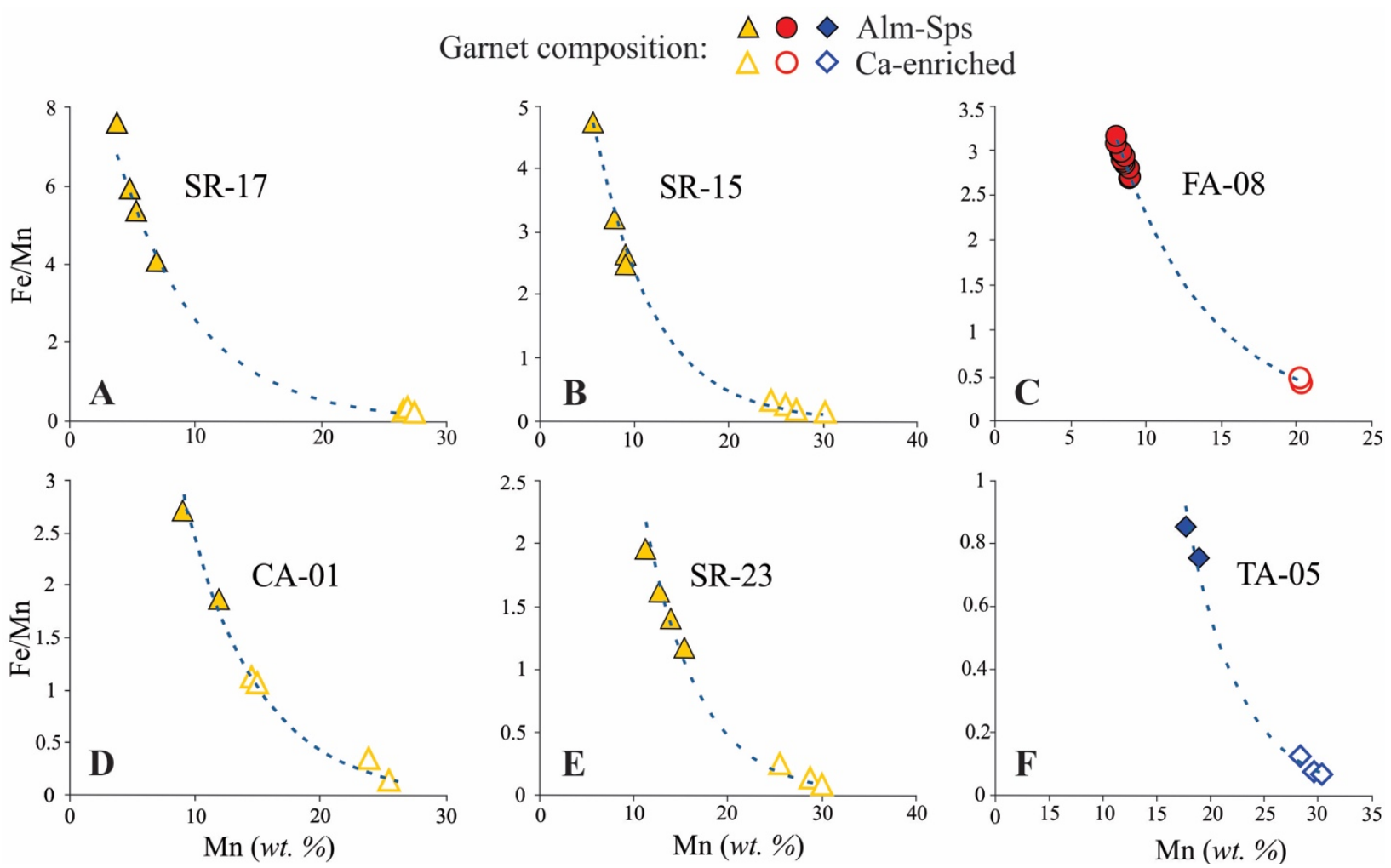

Figure 10. $\mathrm{Fe} / \mathrm{Mn} \times \mathrm{Mn}$ (wt. \%) diagram proposed by Černý et al. (1985) applied to the chemical composition of garnet grains from individual pegmatites of the São João del Rei Pegmatitic Province. The Ca-enriched garnet had the Fe and Mn contents back-calculated, removing the Ca excess. The symbols correspond to the host rocks of the pegmatites. (A, B, D and E) Yellow triangles: Rio das Mortes metavolcano-sedimentary sequence; (C) red circles: Ritápolis metagranitoid; (F) blue diamonds: Resende Costa orthogneiss. 


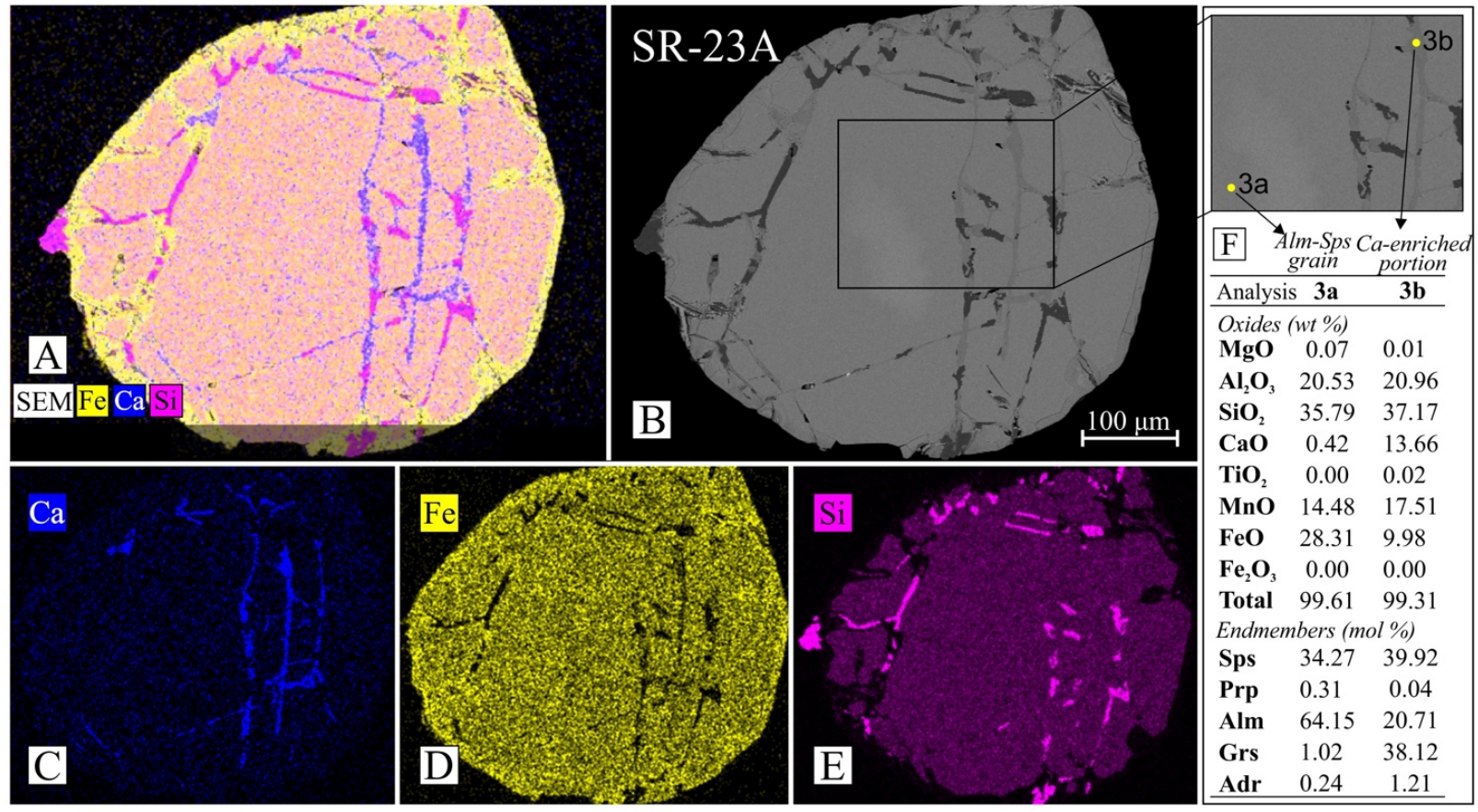

Figure 11. Images and analysis of one Alm-Sps grain of sample SR-23A, a pegmatite hosted by gondites of the Rio das Mortes metavolcanosedimentary sequence. (A) Chemical map for $\mathrm{Fe}, \mathrm{Ca}$ and $\mathrm{Si}$, showing high $\mathrm{Fe}$ content on the edge of the grain due to weathering and a high Ca content in fractures due to the metasomatism; (B) Backscattered electron image; (C) Chemical map for Ca, demonstrating the presence of $\mathrm{Ca}$ enrichment along fractures in the grain; (D) Chemical map for Fe; (E) Chemical map for Si showing quartz filling in fractures as well; (F) Backscattered electron image with the locations of electron microprobe analysis in yellow: (3a) Alm-Sps grain. (3b) Ca-enriched composition in the fracture.

groups due to their different ages and sources. The pegmatites associated to Resende Costa orthogneiss have ages between 2,367 \pm 64 and 2,291 $\pm 23 \mathrm{Ma}$ (Cidade 2019), while the pegmatites correlated to the Ritápolis metagranitoid were formed between 2,129 \pm 33 and 2,121 $\pm 9 \mathrm{Ma}$ (Faulstich 2016). As the Ca-enrichment occurred in these different geochronological pegmatite groups, the contamination of the pegmatite-melt formation seems to be unlikely.

Therefore, it seems that the most probable source of $\mathrm{Ca}$ is the recycling of the own pegmatite minerals. The Ca-enriched garnet must have been formed in each pegmatite for which Ca remained available at the final stage of crystallization. However, more detailed studies are required to improve the understanding of the complex mechanism of late Ca supply that occurs in the São João del Rei Province pegmatites.

\section{CONCLUSIONS}

Two distinct garnet types were identified in the São João del Rei Pegmatitic Province. The garnet grains with typical pegmatitic composition vary from almandine to spessartine defined by the range $\mathrm{Sps}_{11.7-58.8} \mathrm{Alm}_{36.8-86.5} \operatorname{Prp}_{0.1 \text {. }}$ ${ }_{4.1} \mathrm{Grs}_{0.0-1.4} \mathrm{Adr}_{0.0-2.6}$ and the Ca-enriched garnet with range $\mathrm{Sps}_{26.9-84.8} \mathrm{Alm}_{3.6-40.0} \operatorname{Prp}_{0.0-10.4} \mathrm{Grs}_{9.3-45.6} \mathrm{Ad}_{\text {0.1-3.4. }}$.

The use of sedimentary provenance diagrams was important to point out the different genetic trends of the studied garnet. In the Mange and Morton (2007) diagram, the Ca-enriched garnet reflects a chemical composition distinct from what would be expected for pegmatites, plotting in the garnet field associated with low to medium grade metasedimentary rocks. In the Remus et al. (2004) diagram, the Ca-enriched garnet plot outside the field related to pegmatites. An expansion of the garnet field associated to pegmatites (E) in this diagram is proposed to encompass the compositional range of the almandine-spessartine series observed on the garnet grains in the pegmatites of the São João del Rei Pegmatitic Province.

The Alm-Sps grains usually exhibit trapezoidal and dodecahedral forms, as well as scarce mineral inclusions, suggesting that they were formed in the early magmatic crystallization stage of the pegmatites. The $\mathrm{Ca}$-enriched garnet grains exhibit irregular shapes, complex patterns of zonation, features of physicochemical instability and recrystallization, as sinuous and rough surfaces. The Ca-enriched garnet might have occurred at the late-stage crystallization of each pegmatite when Ca release from mineral reequilibration promoted Ca-metasomatism.

\section{ACKNOWLEDGMENTS}

SSCGS acknowledges Coordenação de Aperfeiçoamento de Pessoal de Nível Superior (CAPES) for a Doctoral bursary and CRTI for microprobe WDS analysis. CAA (grants 303377/2014-3,307260/2017-8 and E-26/200.092/2019) and RN (grants 406853/2013-4, 302828/2015-0, 315472/20189) thank Conselho Nacional de Desenvolvimento Científico e Tecnológico (CNPq) and Fundação de Apoio à Pesquisa do Estado do Rio de Janeiro (FAPERJ) for research project grants. We appreciate the careful handling by the editors and the detailed anonymous reviews, which substantially improved the manuscript. 


\section{ARTICLE INFORMATION}

Manuscript ID: 20190136. Received on: 12/19/2019. Approved on: 08/28/2020.

S.S. wrote the manuscript, made the figures, and provided data; C.A. wrote the geology chapter of the manuscript and made corrections and suggestions; R.N. accompanied and helped with the analysis and reviewed the text; F.F. provided data and reviewed the manuscript; F.A. provided data and reviewed the manuscript; T.C. provided data; V.S. improved the manuscript through corrections and suggestions. Competing interests: The authors declare no competing interests.

\section{REFERENCES}

Ackerson M.R., Watson E.B., Tailby N.D., Spear F.S. 2017. Experimental investigation into the substitution mechanisms and solubility of Ti in garnet. American Mineralogist, 102(1):158-172. http://dx.doi.org/10.2138/ am-2017-5632

Alkmim F.F., Martins-Neto M.A. 2012. Proterozoic first-order sedimentary sequences of the São Francisco craton, eastern Brazil. Marine and Petroleum Geology, 33(1):127-139. https://doi.org/10.1016/j. marpetgeo.2011.08.011

Alves F.E.A., Neumann R., Ávila C.A., Faulstich F.R.L. 2019. Monazite-(Ce) and xenotime- $(\mathrm{Y})$ microinclusions in fluorapatite of the pegmatites from the Volta Grande mine, Minas Gerais state, southeast Brazil, as witnesses of dissolution-reprecipitation process. Mineralogical Magazine, 83(4):595606. https://doi.org/10.1180/mgm.2019.43

Anderson A. 1984. The geochemistry, mineralogy and petrology of the CrossLake Pegmatite Field, Central Manitoba. MS Dissertation, Universidade de Manitoba, Winnipeg, $251 \mathrm{p}$.

Araújo A.J.D., Bongiolo E.M, Ávila C.A. 2019. The southern São Francisco Craton puzzle: Insights from aerogeophysical and geological data. Journal of South American Earth Sciences, 94:102203. https://doi.org/10.1016/j. jsames.2019.05.019

Ávila C.A. 2000. Geologia, petrografia e geocronologia de corpos plutônicos paleoproterozoicos da borda meridional do Cráton São Francisco, região de São João del Rei, Minas Gerais. PhD Thesis, Universidade Federal do Rio de Janeiro, Rio de Janeiro, $401 \mathrm{p}$.

Ávila C.A., Bongiolo E.M., Vasques F.S.G., Souza A.N., Seoane J.C.S., Ritins J.I.V., Vilela F.T., Pinheiro M.A.P., Vasconcelos F.F., Cardoso C.D., Silveira V.S.L., Silva P.R.S., Simon M.B., Faulstich F.R.L., Pires G.L.C., Stohler R.C., Oliveira F.V.C.S.R.S., Tedeschi M.F. 2019. Projeto AR IM - Reavaliação das Sequências Metavulcanossedimentares a Sudoeste do Quadrilátero Ferrífero. Mapa Geológico Integrado, escala 1:100.000. Belo Horizonte: Serviço Geológico do Brasil (CPRM).

Ávila C.A., Teixeira W., Bongiolo E.M., Dussin I.A., Vieira T.A.T. 2014. Rhyacian evolution of subvolcanic and metasedimentary rocks of the southern segment of the Mineiro Belt, São Francisco Craton, Brazil. Precambrian Research, 243:221-251. https://doi.org/10.1016/j. precamres.2013.12.028

Ávila C.A., Teixeira W., Cordani U.G., Barrueto H.R., Pereira R.M., Martins V.T.S., Dunyi L. 2006. The Glória quartz-monzodiorite: isotopic and chemical evidence of arc-related magmatism in the central part of the Paleoproterozoic Mineiro Belt, Minas Gerais State, Brazil. Anais da Academia Brasileira de Ciências, 78(3):543-556. https://doi.org/10.1590/ S0001-37652006000300013

Ávila C.A., Teixeira W., Cordani U.G., Moura C.A.V., Pereira R.M. 2010. Rhyacian (2.23-2.20 Ga) juvenile accretion in the southern São Francisco craton, Brazil: Geochemical and isotopic evidence from the Serrinha magmatic suite, Mineiro Belt. Journal of South American Earth Sciences, 29(2):464-482. https://doi.org/10.1016/j.jsames.2009.07.009

Ávila C.A., Teixeira W., Vasques F.S.G., Dussin I.A., Mendes J.C. 2012. Geoquímica e idade UPb (LA-ICPMS) da crosta oceânica Riaciana do Cinturão Mineiro, borda meridional do Cráton São Francisco. In: Congresso Brasileiro Geologia, 46., 2012, Santos. Boletim de Resumos... CD-ROM.

Baldwin J.R., von Knorring O. 1983. Compositional range of Mn-garnet in zoned granitic pegmatites. The Canadian Mineralogist, 21(4):683-688.

Barbosa N.S., Teixeira W., Ávila C.A., Montecinos P.M., Bongiolo E.M. 2015. 2.17-2.10 Ga plutonic episodes in the Mineiro Belt, São Francisco Craton, Brazil: U-Pb ages, geochemical constraints and tectonics. Precambrian Research, 270:204-225. https://doi.org/10.1016/j.precamres.2015.09.010
Barbosa N.S., Teixeira W., Ávila C.A., Montecinos P.M., Bongiolo E.M., Vasconcelos F.F. 2019. U-Pb geochronology and coupled Hf-Nd-Sr isotopic-chemical constraints of the Cassiterita Orthogneiss (2.47-2.41-Ga) in the Mineiro Belt, São Francisco craton: Geodynamic fingerprints beyond the Archean-Paleoproterozoic Transition. Precambrian Research, 326:399416. https://doi.org/10.1016/j.precamres.2018.01.017

Burival Z., Novák M. 2018. Secondary blue tourmaline after garnet from elbaitesubtype pegmatites; implications for source and behavior of Ca and $\mathrm{Mg}$ in fluids. Journal of Geosciences, 63(2):111-122. http://dx.doi.org/10.3190/jgeosci.257

Cardoso C.D., Ávila C.A., Neumann R., Oliveira E.P., Valeriano C.M., Dussin I.A. 2019. A Rhyacian continental arc during the evolution of the Mineiro belt, Brazil: constraints from Rio Grande and Brumado metadiorites. Lithos, 326-327:246-264. https://doi.org/10.1016/j.lithos.2018.12.025

Černý P., Meintzer R.E., Anderson A.J. 1985. Extreme fractionation in rareelement granitic pegmatites: selected examples of data and mechanism. The Canadian Mineralogist, 23(3):381-421.

Cidade T.P. 2019. Mineralogia e idade dos pegmatitos no Ortognaisse Resende Costa, Província Pegmatítica de São João del Rei, Minas Gerais. MS Dissertation, Museu Nacional, Universidade Federal do Rio de Janeiro, Rio de Janeiro, 179 p.

Deer W.A., Howie R.A., Zussman J. 1992. An Introduction to the RockForming Minerals. Harlow: Longman, 696 p.

Droop G.T.R. 1987. A general equation for estimating $\mathrm{Fe}^{3+}$ concentrations in ferromagnesian silicates and oxides from microprobe analyses, using stoichiometric criteria. Mineralogical Magazine, 51(361):431-435. https:// doi.org/10.1180/minmag.1987.051.361.10

Faulstich F.R.L. 2016. Estudo de minerais pesados dos pegmatitos da Província Pegmatítica de São João del Rei, Minas Gerais. PhD Thesis, Universidade Federal do Rio de Janeiro, Rio de Janeiro, 275 p.

Faulstich F.R.L., Ávila C.A., Neumann R., Silveira V.S.L., Callegario L.S. 2016. Gahnite from the São João del rei Pegmatitic Province, Minas Gerais, Brazil: chemical composition and genetic implications. The canadian Mineralogist, 54:1385-1402.

Green T.H. 1977. Garnet in silicic liquids and its possible use as P-T indicator. Contributions to Mineralogy and Petrology, 65(1):59-67. https:// doi.org/10.1007/BF00373571

Grew E.S., Lockock A.J., Mills S.J., Galuskina I.O., Galuskin E.V., Galenius U. 2013. Nomenclature of the garnet supergroup. American Mineralogist, 98(4):785-811. https://doi.org/10.2138/am.2013.4201

Gulbin Y.L., Glazov A.I. 2013. Morphological evidence for diffusioncontrolled growth of garnet from metapelites. Geology of Ore Deposits, 55(8):686-691. https://doi.org/10.1134/S1075701513080059

Harrison T.N. 1988. Magmatic garnets in the Cairngorm granite, Scotland. Mineralogical Magazine, 52(368):659-667. https://doi.org/10.1180/ minmag.1988.052.368.10

Kleck W.D., Foord E.E. 1999. The chemistry, mineralogy, and petrology of the George Ashley Block pegmatite body. American Mineralogist, 84(56):695-707. https://doi.org/10.2138/am-1999-5-601

Locock A.J. 2008. An Excel spreadsheet to recast analysis of garnet into endmember components, and a synopsis of the crystal chemistry of natural silicate garnets. Computer and Geosciences, 34(12):1769-1780. https://doi. org/10.1016/j.cageo.2007.12.013

London D. 2008. Pegmatites. Quebec: Mineralogial Association of Canada, 347 p. Maner J.L., London D., Icenhower J.P. 2019. Enrichment of manganese to spessartine saturation in granite-pegmatite systems. American Mineralogist, 104(11):1625-1637. https://doi.org/10.2138/am-2019-6938 
Mange M.A., Morton A.C. 2007. Geochemistry of heavy minerals. In: Mange M.A., Wright D.T. (eds.). Heavy Minerals in Use. Developments in Sedimentology, 58, p. 345-391. Amsterdam: Elsevier.

Martin R.F., De Vito C. 2014. The late-stage miniflood of Ca in granitic pegmatites: an open-system acid-reflux model involving plagioclase in the exocontact. The Canadian Mineralogist, 52(2):165-181. http://dx.doi. org/10.3749/canmin.52.2.165

Miller C.F., Stoddard E.F. 1981. The role of manganese in the paragenesis of magmatic garnet: an example from the Old Woman-Piute Range, California. Journal of Geology, 89(2):233-246. https://doi.org/10.1086/628582

Morton A.C. 1985. A new approach to provenance studies: electron microprobe analysis of detrital garnets from Middle Jurassic sandstones of the northern North Sea. Sedimentology, 32(4):553-566. https://doi. org/10.1111/j.1365-3091.1985.tb00470.x

Morton A.C., Hallsworth C., Chalton B. 2004. Garnet compositions in Scottish and Norwegian basement terrains: a framework for interpretation of North Sea sandstone provenance. Marine and Petroleum Geology, 21(3):393-410. https://doi.org/10.1016/j.marpetgeo.2004.01.001

Müller A., KearsleyA., Spratt J., Seltmann R. 2012. Petrogenetic implications of magmatic garnet in granitic pegmatites from southern Norway. The Canadian Mineralogist, 50(4):1095-1115. https://doi.org/10.3749/canmin.50.4.1095

Novák M., Kadlec T., Gadas P. 2013. Geological position, mineral assemblages and contamination of granitic pegmatites in the Moldanubian Zone, Czech Republic; examples from the Vlastějovice region. Journal of Geoscience, 58:21-47.

Novák M., Selway J.B., Černý P., Hawthorne F.C. 1999. Tourmaline of the elbaite-dravite series from an elbaitesubtype pegmatite at Bližná, southern Bohemia, Czech Republic. European Journal of Mineralogy, 11 (3):557-568.

Pereira R.M., Ávila C.A., Neumann R. 2004. Estudo mineralógico e químico da cassiterita e de suas inclusões sólidas: implicação com a paragênese das mineralizações da Província Pegmatítica de São João del Rei, Minas Gerais, Brasil. Arquivos do Museu Nacional, 62(3):321-336.

Pieczka A., Szuszkiewicz A., Szełeg E., Nejbert K. 2019. Calcium minerals and late-stage Ca-metasomatism in the Julianna Pegmatitic System, the Gory Sowie Block, SW Poland. The Canadian Mineralogist, 57(5):775-777.

Remus M.V.D., De Ros L.F., Dillenburg S., Splendor F., Nunes L.C. 2004. Aplicação da microssonda eletrônica na análise de proveniência: Granadas - traçadores de áreas-fonte nas Bacias de Santos e Pelotas. Boletim Dez Anos de Microssonda em Porto Alegre, 101-107.

Sabeen H.M., Ramanujam N., Morton A.C. 2002. The provenance of garnet: constraints provided by studies of coastal sediments from Southern India. Sedimentary Geology, 152(3-4):279-287. https://doi.org/10.1016/ S0037-0738(02)00083-0
Seixas L.A.R., David J., Stevenson R. 2012. Geochemistry, Nd isotopes and U-Pb geochronology of a $2350 \mathrm{Ma}$ TTG suite, Minas Gerais, Brazil: Implications for the crustal evolution of the Southern São Francisco craton. Precambrian Research, 196-197:61-80. https://doi.org/10.1016/j. precamres.2011.11.002

Sokolov Y.M., Khlestov V.V. 1989. Garnets as indicators of the physicochemical conditions of pegmatite formation. International Geology Review, 32(11):1095-1107.

Souza A.N. 2009. Evolução petrográfica e gequímica do granitoide Ritápolis, borda meridional do cráton São Francisco. MS Dissertation, Universidade Federal do Rio de Janeiro, Rio de Janeiro, Brazil, 119 p.

Teixeira W., Ávila C.A., Dussin I.A., Corrêa Neto A.V., Bongiolo E.M., Santos J.O., Barbosa N.S. 2015. A juvenile accretion episode $(2.35-2.32 \mathrm{Ga})$ in the Minero belt and its role to the Minas accretionary orogeny: Zircon U-Pb-Hf and geochemical evidences. Precambrian Research, 256:148-169. https:// doi.org/10.1016/j.precamres.2014.11.009

Teixeira W., Ávila C.A., Nunes L.C. 2008. Nd-Sr Isotopic Geochemistry and $\mathrm{U}-\mathrm{Pb}$ Geochronology of the Fé Granitic Gneiss and Lajedo Granodiorite: Implications for Paleoproterozoic Evolution of the Mineiro Belt, Southern São Francisco Craton, Brazil. Geologia USP. Série Científica, 8(1):53-74 https://doi.org/10.5327/Z1519-874x2008000100005

Tindle A.G., Selway J.B., Breaks F.W. 2005. Liddicoatite and associated species from the McCombe spodumenesubtype rare-element granitic pegmatite, northwestern Ontario, Canada. The Canadian Mineralogist, 43(2):769-793. http://dx.doi.org/10.2113/gscanmin.43.2.769

Toledo C.L.B. 2002. Evolução geológica das rochas máficas e ultramáficas no Greenstone Belt Barbacena, na região de Nazareno, MG. PhD Thesis, Universidade Estadual de Campinas, Campinas, 307 p.

Valença J.G., Silva M.A., Schimitt R.S., Trouw R.A.J., Noce C.M. 2000. Transamazonian gabbronoritic intrusive rocks from the southernmost São Francisco Craton (Brazil). In: International Geological Congress, 31., 2000, Rio de Janeiro. Abstracts. Rio de Janeiro. CD-ROM.

Vasconcelos F.F., Ávila C.A., Neumann R., Teixeira W., Bongiolo E.M., Barbosa N., Camara B.O., Menezes V.H., Cunha F.C.M. 2017. Ortognaisse Morro do Resende: mineralogia, petrografia, geoquímica e geocronologia. Geologia USP. Série Científica, 17(1):143-164. http://dx.doi.org/10.11606/ issn.2316-9095.v17-285

Vennum W.R., Meyer C.E. 1979. Plutonic garnets from the Werner batholith, Lassier Coast, Antartic Peninsula. American Mineralogist, 64(3-4):268-273.

Whitworth M.P., Feely M. 1994. The compositional range of magmatic Mngarnets in the Galway granite, Connemara, Ireland. Mineralogical Magazine, 58(390):163-168. https://doi.org/10.1180/minmag.1994.058.390.16 